УДК 550.42:504(571.55)

\title{
КОМПЛЕКСНЫЕ ГЕОХИМИЧЕСКИЕ ИССЛЕДОВАНИЯ КОМПОНЕНТОВ ПРИРОДНОЙ СРЕДЫ В ЭНДЕМИЧНЫХ РАЙОНАХ ЗАБАЙКАЛЬЯ
}

Рихванов Леонид Петрович

Соктоев Булат Ринчинович1, bulatsoktoev@tpu.ru

Барановская Наталья Владимировна', nata@tpu.ru

Агеева Елена Владимировна', ev_ageeva@mail.ru

Беляновская Александра Игоревна ${ }^{1}$, aib28@tpu.ru

Дериглазова Мария Александровна ${ }^{1}$, belyakinama@gmail.com

Юсупов Дмитрий Валерьевич1,2, yusupovd@mail.ru

Эпова Екатерина Сергеевна ${ }^{3}$ apikur1@ya.ru
Солодухина Мария Анатольевна ${ }^{3}$, mabn@ya.ru

Замана Леонид Васильевич, I.v.zamana@mail.ru

Михайлова Лариса Альфредасовна 4 , mihailova-la@mail.ru

Большунова Татьяна Сергеевна5, bts26@mail.ru

Миронова Анастасия Сергеевна', nasie2710@gmail.com

Наркович Дина Владимировна', shvezova_d@mail.ru

Судыко Александр Федорович1, sudykoaf@yandex.ru

Полякова Дарья Анатольевна ${ }^{1}$, darya.darya2012@mail.ru

1 Национальный исследовательский Томский политехнический университет,

Россия, 634050, г. Томск, пр. Ленина, 30.

2 Амурский государственный университет,

Россия, 675027, г. Благовещенск, Игнатьевское шоссе, 21.

3 Институт природных ресурсов, экологии и криологии Сибирского отделения Российской академии наук, Россия, 672002, г. Чита, ул. Недорезова, 16а

4 Читинская государственная медицинская академия, Россия, 672000, г. Чита, ул. Горького, 39а.

${ }^{5}$ АО «ТомскНИПИнефть»,

Россия, 634027, г. Томск, пр. Мира, 72.

Актуальность исследования. Болезнь Кашина-Бека (уровская болезнь) является классическим примером класса эндемических болезней. Однако, в отличие от других болезней, для данного заболевания до сих пор не установлена причина возникновения. $B$ настоящее время в научной литературе обсуждается более 20 теорий и гипотез, объясняющих этиологию и фракторы болезни. Приоритетной теорией является биогеохимическая, согласно которой возникновение и течение болезни зависит от фактора окружающей среды (недостаток/избыток химических элементов или соединений). В связи с этим изучение химического состава компонентов окружающей среды в районе распространения болезни Кашина-Бека является актуальным.

Цель: оценка геохимических особенностей компонентов природной среды на территории юго-восточного Забайкалья - района распространения болезни Кашина-Бека.

Объекты: компоненты природной среды - почва, донные отложения, природные воды (поверхностные, подземные), солевые отложения питьевых вод, керн годовых колец деревьев, листья тополя, лишайники, мхи, полынь, картофрель, волосы детей, кости свиньи домашней.

Методы: элементный состав изученных компонентов природной среды определен методами инструментального нейтронно-активационного анализа и масс-спектрометрии с индуктивно связанной плазмой. Обработка полученных данных включала нормирование содержания химических элементов относительно фоновых показателей (кларк ноосфреры, вода оз. Байкал) и расчет индикаторных отношений.

Результаты. Изучено содержание 26 (по данным инструментального нейтронно-активационного анализа) и 62 (по данным массспектрометрии с индуктивно связанной плазмой) химических элементов в 13 компонентах природной среды. В элементном составе всех изученных компонентов выявлена региональная геохимическая ассоциация (Zn-Pb-Ba-Sb-As-Bi-Au), связанная с особенностями металлогении района. Для проведения будущих исследований наиболее информативными компонентами являются природные воды, костная ткань, волосы детей. Наиболее контрастная геохимическая специализация окружающей среды фрормируется в населенных пунктах, где по литературным данньм наблюдались максимальные уровни заболеваемости болезни Кашина-Бека. Этиология болезни носит многосракторный характер: в развитии заболевания большую роль играют природные условия, что приводит к дисбалансу элементного состава компонентов окружающей среды и, соответственно, организма человека.

Ключевые слова:

Болезнь Кашина-Бека, уровская болезнь, юго-восточное Забайкалье, геохимия окружающей среды, индикаторные отношения. 


\section{Введение}

Геохимические исследования в зависимости от решаемых задач (геологические, экологические) имеют свои особенности и базируются на основных принципах, разработанных как результат их практического использования отечественными и зарубежными исследователями. На сегодняшний день имеется большое количество публикаций (Н.И. Сафонов, А.П. Соловов, С.В. Григорян, В.Л. Барсуков, Л.Н. Овчинников, П.В. Коваль, В.И. Гребенщикова, А. Левинсон и другие), методических инструкций, рекомендаций и указаний для проведения и использования различных геохимических методов в практике геологоразведочных работ: на стадии глобальных, региональных, поисковых и детальных работ в рудных районах, геолого-экономической оценки месторождений. Существующие инструкции, справочники [1] и опубликованные материалы по геохимическим методам поисков рудных месторождений содержат указания о том, какие компоненты окружающей среды (почва, донные отложения, снеговой покров и т. д.) можно использовать в геохимических исследованиях, а также рекомендации по плотности сети отбора проб и минимального количества проб на единицу площади. В этих документах также изложены сведения о методиках подготовки проб и аналитических методах, используемых для определения химического состава. Эти два вопроса являются краеугольными в геохимических работах, независимо от их целевого назначения [2].

Для эколого-геохимических исследований характерна своя специфика: во-первых, за счет расширения объектов исследования (волосы, кровь и другие) и спектра анализируемых элементов, во-вторых, необходимо учитывать больше внешних факторов, таких как роза ветров и время опробования. В ряде исследований используется подход с отбором сопряженных (максимально близких в пространстве) проб различных компонентов природной среды. При обработке полученных данных используются специфические геохимические показатели, например суммарный показатель загрязнения (СПЗ), коэффициент концентрации (КК) и другие.

Подходы к решению экологических задач с использованием геохимических методов были заложены в работах А.А. Беуса, Н.Ф. Глазовского, М.А. Глазовской, В.И. Гребенщиковой, В.Б. Ильина, П.В. Коваля, И.С. Ломоносова, Т.А. Олигер, Ю.Г. Покатилова, Б.А. Ревича, Н.А. Рослякова, Ю.Е. Саета, Р.Р. Брукса, А. Кабата-Пендиас, Дж.В. Мура, К. Турекьяна. В данных работах обсуждается вопрос об экологической оценке состояния окружающей среды, хотя проблема взаимосвязи элементного состава живых организмов и особенностей их функционирования с точки зрения биогеохимии стала предметом исследования гораздо раньше (А.П. Виноградов, В.В. Ковальский и другие) как продолжение геохимических идей В.И. Вернадского в развитии биосферы. К этому времени следует отнести формирование задачи по созданию базы данных о геохимии компонентов природ- ной среды, находящейся под влиянием живых организмов.

Следующим шагом явилось применение картографических методов в практике экологогеохимических исследований. В 1972 г. под руководством В.В. Ковальского была составлена первая биогеохимическая карта СССР, на которой были выделены зоны избыточного и недостаточного накопления химических элементов с точки зрения функционирования живых организмов. На этой карте также были отмечены известные на тот момент времени эндемичные районы, в том числе район уровской эндемии в Забайкалье.

За последнее время появились новые термины, тесно связанные с экологической направленностью геохимических исследований: «геохимия окружающей среды», «экологическая геохимия» (Ю.Е. Сает), «геохимическая экология» (В.В. Ковальский), «геохимическая экология болезней» (В.Л. Сусликов), «медицинская геология» (O. Selinus), в которых широко применяются классические методы, используемые геологами. При этом изучаются геохимические особенности не одного компонента (почва, вода, воздух), а их группы с включением косного и биокосного вещества, что требует исследования живого вещества на различных уровнях его организации.

Многолетние исследования большого количества компонентов природной среды, проведенные на разных территориях и с различными задачами, привели авторов к выводу, что решение проблем состояния и прогнозирования здоровья человека, особенно в случаях с неустановленной этиологией, требует комплексного подхода к проведению медико-экологического мониторинга. Такой подход может помочь в выявлении первопричин заболеваемости населения и распространения определённого заболевания.

Анализ накопленного фактического материала позволил выработать ряд общих методологических подходов к проведению оценки экологогеохимического состояния территорий со сложным характером техногенного воздействия и организации последующего мониторинга. При этом должны соблюдаться следующие базовые принципы:

1) исследования должны выполняться комплексно и базироваться на использовании геохимических и геофизических методов при изучении различных компонентов природной среды;

2) оценку степени трансформации различных компонентов природной среды необходимо выполнять максимально сближено во времени и в пространстве;

3) в исследование необходимо вовлекать депонирующие компоненты природной среды, способные сохранять загрязняющие вещества в течение длительного времени, а временные интервалы поступления поллютантов можно достаточно четко устанавливать в стратифицированных образованиях (торф, годовые кольца деревьев, донные отложения озер, волосы и другие); 
4) отбор и подготовку проб, а также анализ элементного состава необходимо проводить по единым методикам с применением высокочувствительных аналитических методов (например, ИНАА, ИСПМС, РФА-СИ), стандартных образцов сравнения на базе аккредитованных лабораторий, при этом следует определять максимально возможный спектр химических компонентов (тяжелые металлы, радиоактивные и редкоземельные элементы, основные органические соединения), микробиологический состав вод, почв и т. Д.;

5) следует использовать геохимические и биоиндикаторные показатели (хромосомные аберрации, микроядерный тест и другие), особенно в районах, где присутствуют сложные химические и радиационные факторы воздействия;

6) картографическую привязку точек отбора следует осуществлять в единой системе координат, а создание карт проводить с использованием современных ГИС-технологий;

7) математическая обработка данных, построение моно- и полифункциональных карт осуществляется по единым методикам.
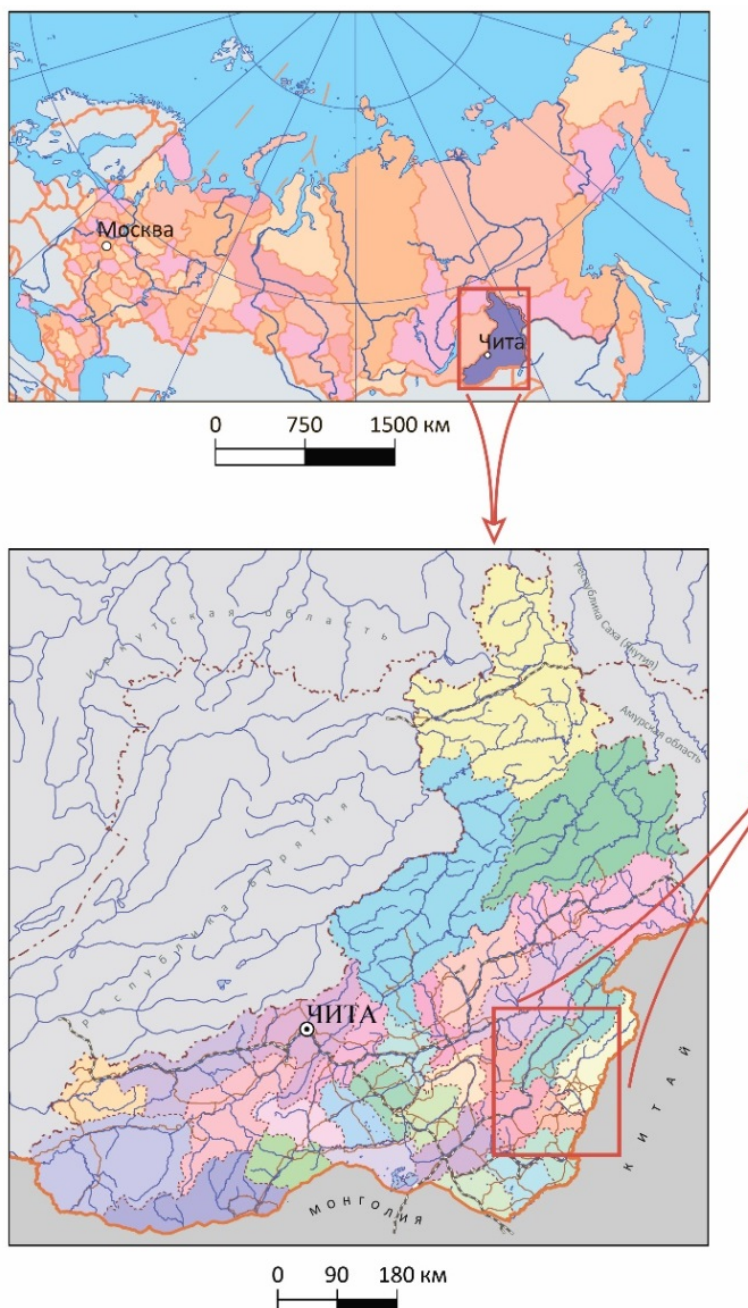

Параллельно с геохимическими исследованиями специалистами-медиками на изучаемой территории проводится сбор медицинских данных, отбор проб для анализа медицинских показателей.

Именно такой подход к анализу и оценке ситуации был назван нами медико-эколого-геохимическим мониторингом и реализован в 1993-2006 гг. на территории Томского района. Этот подход используется нами и в других исследованиях, но, к сожалению, без широкого проведения медицинских исследований [3].

Описанное в данной статье исследование базируется на этом же подходе.

\section{Характеристика района исследования}

Рассматриваемый район (юго-восток Забайкалья) известен в научной литературе как первый установленный очаг распространения классического примера эндемической болезни - болезни Кашина-Бека (БКБ, уровская болезнь, Kashin-Beck disease - KBD) (рис. 1).

Согласно литературным данным ареал заболевания установлен не только в данном регионе, но также и в Амурской области, Китае, Вьетнаме и Корее [5-9]. В районах проявления болезни Кашина-Бека проживает не менее 38 миллионов человек $[8,10,11]$.

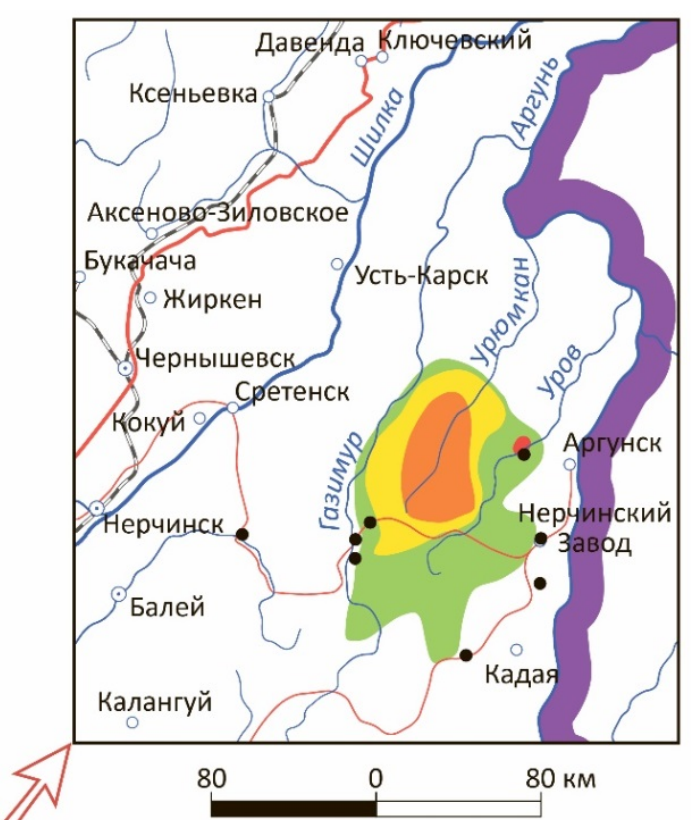

ровень заболеваемости

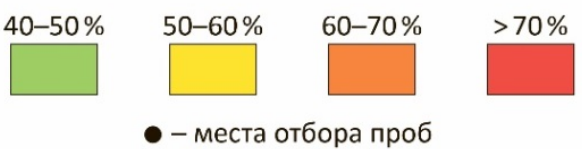

Рис. 1. Район исследования: схематическая карта распространения болезни Кашина-Бека в Восточном Забайкалье (основана на материалах карты [4]) и места отбора проб

Fig. 1. Investigation area: schematic map of Kashin-Beck disease spatial distribution (based on the map [4]) and sampling sites 
Болезнь проявляется в виде деформирующего хондроостеоартроза, поражающего опорно-двигательный аппарат; в крайних формах внешне выражена в виде низкорослости, короткопалости рук («медвежья лапа»), деформации скелета, что, в конечном счете, приводит к потере трудоспособности. Болезнь развивается преимущественно в детском и юношеском возрасте: пик заболеваемости приходится на возраст 8-19 лет, при этом болезнь развивается 5-8 лет.
Район распространения БКБ в Восточном Забайкалье приурочен к весьма сложной геологической структуре длительного развития, известного под общим названием Монголо-Охотский складчатый пояс. В пределах этой части пояса развиты породы докембрия (гранитогнейсовые купольные структуры), кембрия (карбонатнотерригенные осадочные отложения), юры и мела (вулканогенно-осадочные толщи), которые сохранились в наложенных впадинах типа грабен-синклиналей (рис. 2).

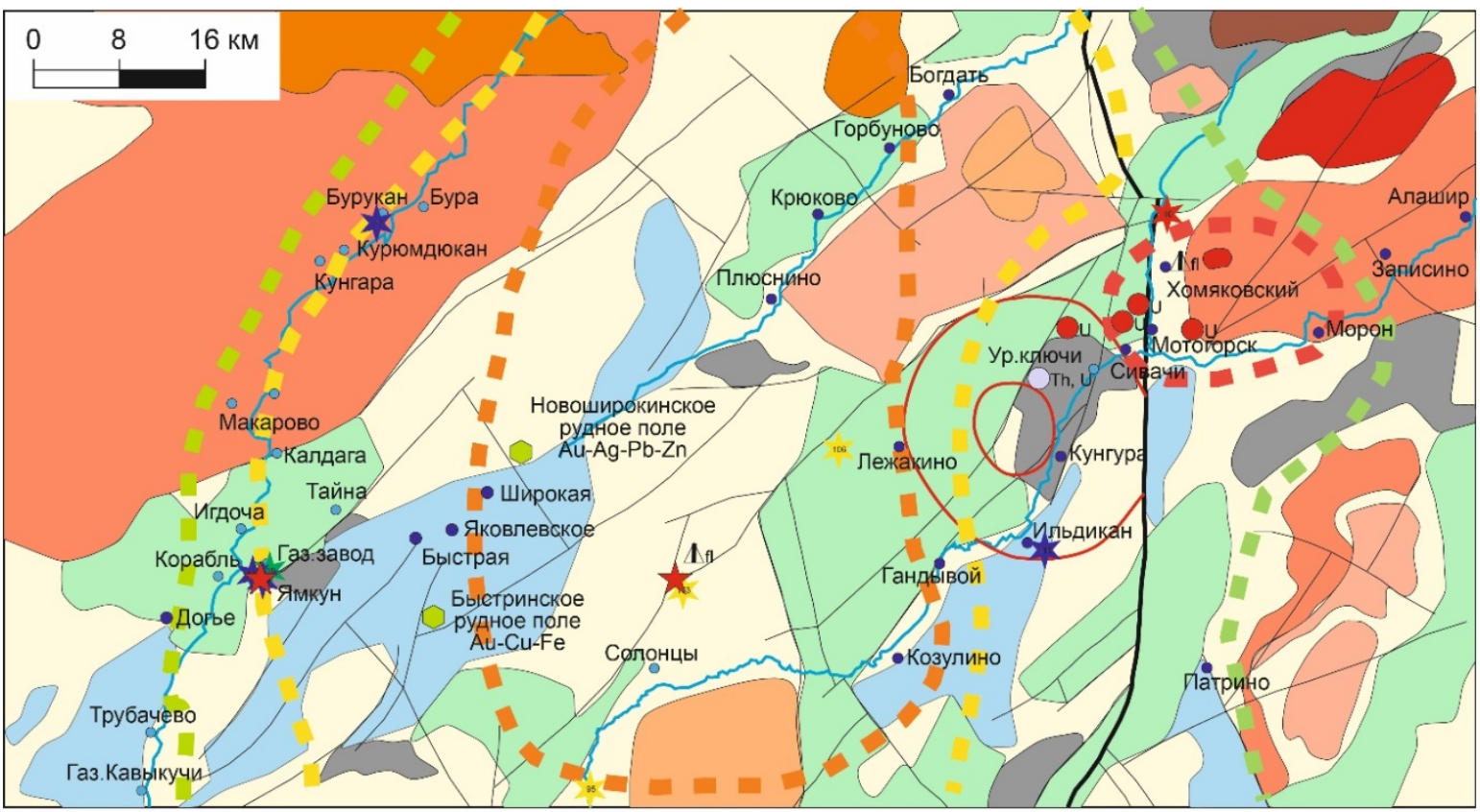

\section{Условные обозначения}

Вулканогенно-осадочные породы

$\square$ Меловые
$\square$ Юрские
$\square$ Кембрийские
$\square$ Докембрийские
$\square$ Разрывные
нарушения
Кольцевая
структура

Интрузивные породы

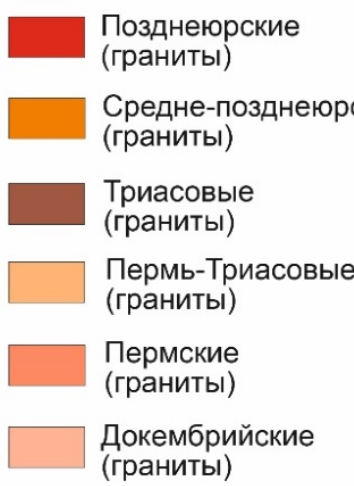

Населенные пункты

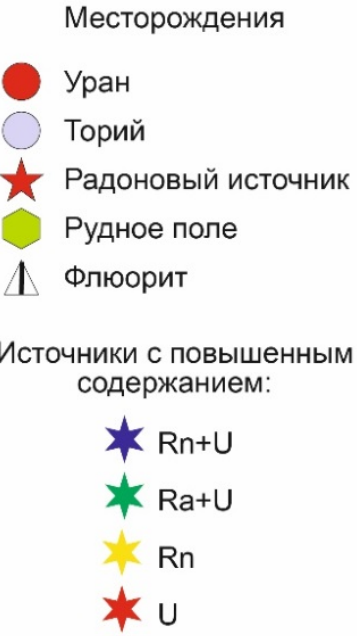

- Существующие • Несуществующие

Уровень заболеваемости

$$
\text { - }
$$

Рис. 2. Схематическая геологическая карта района исследований с элементами металлогении (масштаб 1:500000). Примечание: карта составлена по геологической карте масштаба 1:200000 на основе государственных листов M-50-V, M-50-VI [12]. Уровни заболеваемости приведены по [4]

Fig. 2. Schematic geological map of the investigation area with the metallogenic aspects (map scale 1:500000). Note: the map is based on the geological map (map scale 1:200000, national chart sheets M-50-V, M-50-VI [12]. Incidence rates are given after [4]) 
Основные тектонические нарушения, среди которых главным является Пограничный разлом, имеют северо-восточное простирание. Многочисленные разрывные структуры других порядков разделяют район на геологические блоки.

В районе развиты интрузивные комплексы разного возраста и состава, в том числе имеющие ярко выраженные радиогеохимические особенности как U, так и Тh природы. Рядом исследователей в пределах данной территории выделен Урюмкано-Уровский радиоэкологический район с особой обстановкой.

В металлогеническом плане район исследования входит в Агинскую металлогеническую провинцию [12] с проявлением разнообразных и разномасштабных месторождений и рудопроявлений (от крупнейшего в мире Стрельцовского урановорудного узла на юго-востоке до Быстринского и Новоширокинского рудных полей на северо-западе). Непосредственно в районе выделяется Мотогорский Sn-U-F рудный узел с проявлениями $\mathrm{Th}, \mathrm{Zn}, \mathrm{Cu}, \mathrm{Mo}, \mathrm{Pb}, \mathrm{As}, \mathrm{Bi}, \mathrm{Au}, \mathrm{Hg}$ и других металлических и неметаллических видов полезных ископаемых, в том числе минеральных вод с $\mathrm{Rn}$ (Ямкун, Солонешное и другие). В пределах района по данным радиогеохимического картирования широко развиты водные источники $\mathrm{Rn}, \mathrm{Rn}-\mathrm{U}, \mathrm{Rn}-\mathrm{Ra}, \mathrm{U}$ природы.

Bсё это позволяет предположить, что геологические, ландшафтно-геоморфологические, гидрогеологические, геохимические и другие факторы либо их сочетанное (синергетическое) воздействие в целом могут быть одной из причин развития болезни Кашина-Бека.

\section{Проблема этиологии болезни Кашина-Бека}

На территории нынешнего Забайкальского края в разные годы проводились исследования данного заболевания, в том числе с использованием рентгенодиагностики (1930-1932 гг. - Н.И. Дамперов, 1940-1945 гг. - Ф.П. Сергиевский, 1951-1958 гг. Л.Ф. Кравченко, 1978-1993 гг. - А.В. Вощенко и другие), которые в большинстве случаев отмечали тенденцию к уменьшению уровня заболеваемости БКБ. По результатам исследований была составлена карта распространения болезни в Восточном Забайкалье, разработана классификация поражений организма при болезни, предложена Р-Mn модель заболевания, сформулированы методические рекомендации по лечению болезни, создан музей с коллекцией препаратов и скелетов больных.

Согласно официальным данным, начиная с 1987 г., новых случаев заболевания в Забайкальском крае не отмечено. Хотя, по мнению И.В. Холмогоровой, главного врача ГУЗ «Краевой центр медицинской реабилитации Ямкун» (устное сообщение, 2017 г.), пациенты с симптомами БКБ появляются.

Причины возникновения заболевания изучаются специалистами уже более 170 лет, что привело к существованию более чем 20 гипотез, ведущими из них являются биогеохимические и микробиологические (табл. 1).

Таблица 1. Список теорий по этиологии болезни Кашина-Бека и их авторы

Table 1. List of theories on Kashin-Beck disease etiology and their authors

\begin{tabular}{|c|c|}
\hline Теория/Theory & Авторы/Authors \\
\hline $\begin{array}{l}\text { заболоченность и ржавость воды } \\
\text { water marshiness and rustiness }\end{array}$ & $\begin{array}{l}\text { И.А. Юренский, Н.И. Кашин } \\
\text { I.A. Yurenskiy, N.I. Kashin }\end{array}$ \\
\hline $\begin{array}{l}\text { растворенные в воде минералы, в том числе коллоидное } \mathrm{Au} \\
\text { minerals dissolved in water, including colloidal } \mathrm{Au}\end{array}$ & $\begin{array}{l}\text { Е.В. Бек, Н.Л. Сакович, В.Г. Шипачев } \\
\text { E.V. Beck, N.L. Sakovich, V.G. Shipachev }\end{array}$ \\
\hline $\begin{array}{l}\text { радиоактивность воды } \\
\text { water radioactivity }\end{array}$ & $\begin{array}{l}\text { И.А. Багашев } \\
\text { I.A. Bagashev }\end{array}$ \\
\hline $\begin{array}{l}\text { алиментарно-токсическая } \\
\text { alimentary-toxic }\end{array}$ & $\begin{array}{l}\text { Ф.П. Сергиевский, Л.Ф. Кравченко } \\
\text { F.P. Sergievskiy, L.F. Kravchenko }\end{array}$ \\
\hline $\begin{array}{l}\text { дефицит Са и избыток Р (Ca-P) } \\
\text { Ca deficiency and P abundance (Ca-P) }\end{array}$ & $\begin{array}{l}\text { А.П. Виноградов, П.Н. Палей } \\
\text { A.P. Vinogradov, P.N. Paley }\end{array}$ \\
\hline $\begin{array}{l}\text { дефицит Са и избыток } \mathrm{Sr}(\mathrm{Ca}-\mathrm{Sr}) \\
\text { Ca deficiency and } \mathrm{Sr} \text { abundance }(\mathrm{Ca}-\mathrm{Sr})\end{array}$ & $\begin{array}{l}\text { B.В. Ковальский, В.В. Ермаков, И.А. Самарина, В.Г. Хоботьев, В.С. Бутко } \\
\text { V.V. Kovalsky, V.V. Ermakov, I.A. Samarina, V.G. Khobotev, V.S. Butko }\end{array}$ \\
\hline $\begin{array}{l}\text { избыток Р и Mn } \\
\mathrm{P} \text { and } \mathrm{Mn} \text { abundance }\end{array}$ & $\begin{array}{l}\text { A.В. Вощенко, Л.В. Зайко, Н.Н. Алексенцева } \\
\text { A.V. Voschenko, L.V. Zayko, N.N. Aleksentseva }\end{array}$ \\
\hline дефицит Se/Se deficiency & $\begin{array}{l}\text { китайские ученые, Л.В. Аникина, Л.П. Никитина } \\
\text { Chinese scientists, L.V. Anikina, L.P. Nikitina }\end{array}$ \\
\hline
\end{tabular}

Еще начиная с работ А.П. Виноградова в качестве индикаторных показателей для выделения неблагополучных по болезни БКБ территорий использовались отношения химических элементов. Самыми распространенными индикаторными отношениями, согласно литературным данным, являются $\mathrm{Ca} / \mathrm{Sr}, \mathrm{Ca} / \mathrm{P}, \mathrm{Ca} / \mathrm{Mn}, \mathrm{P} / \mathrm{Mn}$. Данные отношения наиболее часто используются в исследованиях, посвященных районам распространения БКБ, в том числе и на территории Китая, где в настоящее время находится мировой центр изучения болезни Кашина-Бека.

Именно китайскими исследователями была предложена приоритетная на настоящий момент теория, объясняющая происхождение заболевания, - дефицит
$\mathrm{Se}$ (гипоселеноз) в окружающей среде и его биодоступности [13-16]. Рядом российских исследователей данная точка зрения также переносится и на территорию Забайкальского края [17].

\section{Материалы и методы исследования}

С целью выявления геохимической специализации компонентов природной среды в районе проявления болезни Кашина-Бека авторы статьи провели комплексные исследования в населенных пунктах (н.п.), в которых 70-80 лет назад фиксировались повышенные уровни заболеваемости (Тайна, Уровские Ключи), и населенных пунктах, где болезнь не была выявлена (Калга). Дополни- 
тельно были отобраны пробы некоторых компонентов природной среды в других населенных пунктах (рис. 1).

Каждый из отобранных компонентов природной среды обладает своими особенностями накопления химических элементов, временем депонирования и индикаторными свойствами. Для исследования отбирался материал, представленный как косным, так и живым веществом биосферы (табл. 2).

Таблица 2. Компоненты природной среды, изученные в данном исследовании

Table 2. Environmental components investigated in the current study

\begin{tabular}{|c|c|c|c|}
\hline $\begin{array}{c}\text { Компонент природной среды } \\
\text { Environmental component }\end{array}$ & $\begin{array}{c}\text { Количество проб } \\
\text { Number of samples }\end{array}$ & $\begin{array}{c}\text { Количество химических элементов } \\
\text { Number of chemical elements }\end{array}$ & $\begin{array}{c}\text { Метод анализа } \\
\text { Analytical method }\end{array}$ \\
\hline Почва/Soil & 3 & 28 & \multirow{2}{*}{ ИНАА/INAА } \\
\hline Донные отложения/Bottom sediments & 7 & 28 & \\
\hline Природные воды/Natural waters & 8 & 62 & ИСП-МС/ICР-МS \\
\hline $\begin{array}{l}\text { Солевые отложения питьевых вод } \\
\text { Drinking water salt sediments }\end{array}$ & 6 & 28 & \multirow{8}{*}{ ИНАА/INAА } \\
\hline Картофель/Potato & 4 & 28 & \\
\hline $\begin{array}{l}\text { Керн годовых колец деревьев } \\
\text { Core of tree rings }\end{array}$ & 7 & 28 & \\
\hline Листья тополя/Poplar leaves & 17 & 28 & \\
\hline Лишайник/Lichen & 9 & 28 & \\
\hline Mox/Moss & 7 & 28 & \\
\hline Полынь/Wormwood & 9 & 28 & \\
\hline Волосы детей & \multirow{2}{*}{5} & 28 & \\
\hline Children hair & & 62 & ИСП-МС/ICР-МS \\
\hline Кости свиньи домашней & \multirow{2}{*}{10} & 28 & ИНАA/INAA \\
\hline Bone of domestic pig & & 62 & ИСП-МС/ICР-МS \\
\hline
\end{tabular}

Примечание: ИНАА - инструментальный нейтронно-активационный анализ, ИСП-МС-масс-спектрометрия с индуктивно связанной плазмой.

Note: INAA - instrumental neutron activation analysis, ICP-MS - inductively coupled plasma mass-spectrometry

Элементный состав всех проб, кроме природных вод, был определен методом ИНАА в ядерно-геохимической лаборатории Международного инновационного научнообразовательного центра (МИНОЦ) «Урановая геология» на базе исследовательского ядерного реактора ИРТ-Т НИ ТПУ (аттестат аккредитации № RA.RU.21АБ27 от 27.05.2015 г., аналитики А.Ф. Судыко, Л.В. Богутская). Было определено содержание 28 химических элементов ( $\mathrm{Na}, \mathrm{Ca}, \mathrm{Sc}, \mathrm{Cr}, \mathrm{Fe}$, $\mathrm{Co}, \mathrm{Zn}, \mathrm{As}, \mathrm{Br}, \mathrm{Rb}, \mathrm{Sr}, \mathrm{Ag}, \mathrm{Sb}, \mathrm{Cs}, \mathrm{Ba}, \mathrm{La}, \mathrm{Ce}, \mathrm{Nd}, \mathrm{Sm}$, $\mathrm{Eu}, \mathrm{Tb}, \mathrm{Yb}, \mathrm{Lu}, \mathrm{Hf}, \mathrm{Ta}, \mathrm{Au}, \mathrm{Th}, \mathrm{U})$.

Пробы природных вод, волос детей и костей свиньи домашней были дополнительно проанализированы методом ИСП-МС в ООО «Химико-аналитический центр "Плазма"» (г. Томск, аттестат аккредитации № POCC.RU.0001.516895 от 25.03.2014 г., директор H.В. Федюнина) и Проблемной научноисследовательской лаборатории гидрогеохимии ИШПР НИ ТПУ (зав. лабораторией - А.А. Хващевская). Количество химических элементов, определенных данным методом, составило 62.

Полученные данные по содержанию химических элементов обрабатывались следующим образом: рассчитывались коэффициенты концентрации (КК) относительно кларка ноосферы [18], далее строились геохимические ряды, в которых особое внимание обращалось на значения КК $>1,5$. Данные по природным водам нормировались к элементному составу воды 03. Байкал [19]. Были также рассчитаны индикаторные отношения, как широко обсуждаемые при рассмотрении проблемы БКБ $(\mathrm{Ca} / \mathrm{Sr}, \mathrm{Ca} / \mathrm{Mn}$, $\mathrm{P} / \mathrm{Mn}, \mathrm{Ca} / \mathrm{P})$, так и используемые нами $(\mathrm{Ca} / \mathrm{Ba}, \mathrm{La} / \mathrm{Yb}$ $\mathrm{La} / \mathrm{Th}, \mathrm{Br} / \mathrm{U}, \mathrm{Th} / \mathrm{U})$ при эколого-геохимическом мониторинге.

\section{Результаты и их обсуждение}

Данная статья посвящена анализу показателей (коэффициенты концентрации, геохимические ряды, индикаторные отношения) для получения генерализованных выводов о сходстве и различии геохимических особенностей компонентов окружающей среды в районах проявления БКБ и вне таковых.

Почва является долговременной депонирующей средой и считается основным объектом экологогеохимического мониторинга. Ее изучение требует определенного опыта, особенно интерпретации полученных данных, так как она может наследовать состав и геохимические особенности подстилающих пород (автохтонные) либо представлять собой перемещенный материал, имеющий мало связи с материнскими породами (аллохтонные) [20-24].

Для почв изученного района в силу специфики их формирования (климатические условия, сложный горный рельеф, многолетняя мерзлота и другие факторы) характерны некоторые черты, отличающие их от основных зональных почв. Мерзлотные луговолесные и лугово-черноземные почвы являются основным фондом сельскохозяйственных угодий региона, в том числе в районе, где проводился отбор проб.

Анализ некоторых геохимических особенностей почв показывает, что максимальное количество (17 из 26) химических элементов с КК $>1,5$ характерно для образцов из с. Уровские Ключи, минимальное (6 химических элементов) - с. Тайна. Повышенные (относительно кларка ноосферы) КК во всех пробах почв выявлены для $\mathrm{Sr}$, и только в пробах из с. Тайна в геохимическом ряду присутствует Са. Для почв района выявлена Ba-Sb-As-Zn специализация, к которой в населенных пунктах Уровские Ключи и Калга добав- 
ляется Аu. Данная геохимическая специализация, вероятнее всего, связана с наличием двух крупных рудных узлов Аu-полиметаллического (Широкинский) и

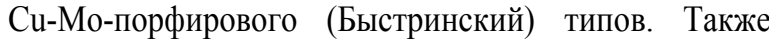
необходимо отметить присутствие U в геохимических рядах в пробах из сел Уровские Ключи и Калга (КК 1,8 и 3,4 , соответственно).

Значения рассчитанных индикаторных отношений некоторых химических элементов достаточно дифференцированы. Так, минимальное (69) значение отношения $\mathrm{Ca} / \mathrm{Sr}$ зафиксировано в с. Калга, максимальное (107) - в с. Тайна. Примерно такие же значения данного отношения приведены в работе Н.Н. Алексенцевой [25]: от 180 в эндемичной зоне проявления БКБ до 142 в контрольном районе. Отношение $\mathrm{Ca} / \mathrm{Ba}$ принимает максимальные значения в с. Уровские Ключи (31), а минимальные - в с. Тайна (15). Для почв с. Тайна также характерны минимальные значения отношений $\mathrm{La} / \mathrm{Yb}(15), \mathrm{La} / \mathrm{Th}(2,5), \mathrm{Th} / \mathrm{U}(0,7)$. При этом для данного населенного пункта характерно максимальное значение отношения $\mathrm{Br} / \mathrm{U}(29,5)$, что выделяет с. Тайна по сравнению с другими изученными пунктами.

Донные отложения - сравнительно редкий компонент природной среды в эколого-геохимических исследованиях [26-28]. Однако в нашей работе они имеют важное значения при рассмотрении геохимических особенностей бассейнов местных рек.

Анализ геохимических особенностей донных отложений района распространения БКБ указывает, прежде всего, на золоторудную специализацию региона. Для четырех изученных водотоков характерна тесная ассоциация $\mathrm{Au}-\mathrm{Sb}-\mathrm{As}-\mathrm{Ba}$, разница наблюдается лишь в положении данной группы химических элементов в геохимических рядах. Только лишь в донных отложениях из р. Анчор (с. Калга) в геохимических рядах отсутствуют As и $\mathrm{Ba}$, в пределах данного населенного пункта за все время наблюдений за БКБ не фиксировалось или редко фиксировалось данное заболевание. В свою очередь, для донных отложений p. Тайна характерны низкие концентрации Тh и U $(\mathrm{KK}<1,5)$.

При анализе индикаторных отношений необходимо обратить внимание на их минимальные значения в донных отложениях р. Анчор, за исключением $\mathrm{Br} / \mathrm{U}$ $(9,9)$, и максимальные значения в образцах из р. Тайна.

Природные воды. Поверхностные водотоки, которые до середины XX в. использовались как источники водоснабжения, и подземные воды в районе исследования изучаются давно (работы И.А. Багашева, А.П. Виноградова, Л.В. Зайко, В.Г. Хоботьева, В.Г. Шипачева, Л.К, Магнушевского, Н.Н. Алексенцевой, Л.В. Заманы и многих других ученых).

Так, в работе [29] показано, что на территории исследуемого района подземные и поверхностные воды пресные, преимущественно гидрокарбонатные, двухили трехкомпонентные по катионам с преобладанием Са. Заметно различаются химические характеристики вод в зависимости от приуроченности к геологическим комплексам и ландшафтным зонам. Наиболее контрастные гидрогеохимические аномалии связаны с карбонатными породами быстринской свиты и вулканогенными породами гидаринской и годымбойской свит. Минерализация приуроченных к ним вод составляет в среднем 570, 208, 248 мг/л, соответственно; содержание $\mathrm{Ca}-73,27,5,28,2$ мг/л; $\mathrm{Sr}-0,37,0,22$, 0,21 мг/л; $\mathrm{P}_{\text {общ }}-0,047,0,134,0,118$ мг/л [29]. Как видно, содержание Са в водах, приуроченных к карбонатным породам, в 2,5 раза выше, чем водах, приуроченных к эффузивным породам. Эти данные хорошо согласуются с результатами исследований А.П. Виноградова, согласно которым заболевание не проявляется на участках распространения карбонатных пород, несмотря на более высокое содержание $\mathrm{Sr}$ в водах. Данные по Са и $\mathrm{Sr}$ в природных водах, в том числе по отдельным водоносным горизонтам, также хорошо согласуются с выводами А.П. Виноградова [30]. Coдержания Р в целом подтверждают выводы авторов P-Mn гипотезы [31]: аномалии связаны не только с болотными ландшафтами, но и водами, развитыми по вулканогенным породам. Так, максимальное содержание Р (3,46 мг/л) выявлено в роднике, дренирующем базальты годымбойской свиты на суходольном участке без многолетней мерзлоты. Отношение $\mathrm{Ca} / \mathrm{P}$ в очагах БКБ в большинстве случаев меньше 300.

В гидрогеохимическом плане аномалии Р вызывают интерес даже вне связи с БКБ. По данным изучения более чем 550 проб к аномальным отнесены пробы с содержанием общего Р более 0,1 мг/л. Кроме того, в этих же пробах определялось содержание органического Р. Согласно результатам, в пробах с фоновым содержанием Р на его органическую форму приходится около 50 \%, в то время как в аномалиях преобладает минеральная форма. Расчет равновесия в пробах вод с высоким содержанием Р показывает насыщение по апатиту, что ставит вопрос о форме нахождения этого химического элемента в горных породах (чаще всего, это апатит). Вероятно, насыщение по апатиту в водах достигается в результате образования полифосфатной формы, наличие которой было выявлено единичными определениями, в том числе и по данным Н.Н. Алексенцевой [25].

В свою очередь, аномалий по $\mathrm{Mn}$ не выявлено, также в аномальных по Р водах выявлены повышенные содержания Si. Среди тяжелых металлов в водах данного района выделяются $\mathrm{Cu}, \mathrm{Mo}, \mathrm{Pb}$ : по последнему элементу выделяется участок в пределах левобережья р. Уров в поле развития базальтов годымбойской свиты, где содержание $\mathrm{Pb}$ достигает 27 мкг/л (ПДК для питьевых вод - 30 мкг/л). Повышенные концентрации данных элементов также установлены в костях больных БКБ $[32,33]$.

При анализе геохимических рядов коэффициентов концентрации (относительно воды о3. Байкал) для подземных вод выделяется проба из с. Тайна, в которой отмечено максимальное количество элементов с KК>1,5 - 24, среди которых Tl, Ge, Li, Pb, Cu, Sb, W и другие. В пробах из с. Калга отмечены высокие КК для $\mathrm{Hg}(773)$ и U (35).

Отношение $\mathrm{Ca} / \mathrm{Sr}$ колеблется от 87 (с. Калга) до 481 (с. Уровские Ключи), отношение $\mathrm{Ca} / \mathrm{Ba}$ варьирует в пределах от 974 (с. Тайна) до 3157 (с. Уровские 
Ключи). Весьма интересно распределение показателя $\mathrm{Ca} / \mathrm{Mn}:$ минимальное значение отмечается в с. Тайна (1732), максимальное - в с. Калга (4862).

Геохимические ряды для поверхностных вод показывают, что максимальное количество химических элементов с КК $>1,5$ зафиксировано в пробе из р. Газимур (30), в том числе Ti, $\mathrm{Zr}, \mathrm{Sm}, \mathrm{Gd}$, Th, что значительно отличается от других водотоков района. Вероятно, это отражает особенности геологического строения бассейна реки, в пределах которого распространены гранитоиды. Для пробы из р. Тайна отмечено присутствие 28 химических элементов, в том числе As (КК - 21), в образцах р. Уров отмечено 16 элементов, практически без каких-либо специфических компонентов. Специфичные компоненты также отсутствуют в воде р. Анчор. В этом плане весьма интересно смотрится Ямкун - поверхностный водоем озерного типа со слабой рассеянной нагрузкой, описанный нами ранее [34]. В этом водоеме отмечено 12 химических элементов, таких как Be, Cs, Tl, Y, W, свидетельствующих о происхождении, которое, вероятно, связано с щелочными гранитоидами. По $\mathrm{Ca}, \mathrm{Sr}$, $\mathrm{Mn}$ изученные поверхностные водотоки мало отличаются, за исключением оз. Ямкун.

Отношение $\mathrm{Ca} / \mathrm{Sr}$ колеблется от 91 (р. Газимур) до 205 (оз. Ямкун); Сa/Ba - от 1177-1178 (р. Газимур, оз. Ямкун) до 2089 (р. Анчор), в р. Уров оно составляет 1620.

Солевые отложения питьевых вод (накипь), образующиеся в бытовых условиях после кипячения, являются новым компонентом в эколого-геохимических исследованиях, который обладает достаточно большой информативностью. Геохимические особенности данных образований отражают состав питьевой воды и в общем случае являются индикатором ее качества $[35,36]$.

Анализ полученных данных показывает, что в накипи накапливается небольшое количество химических элементов (6-7) с КК>1,5. К ним относятся Са и $\mathrm{Sr}(\mathrm{KК}>10)$, которые есть во всех пробах, кроме проб из с. Нерчинский Завод. Естественно, что отношение $\mathrm{Ca} / \mathrm{Sr}$ в данном населенном пункте максимально (1076), в свою очередь минимальное отношение отмечается в пробах из г. Борзя (137). Обращает на себя внимание, что во всех изученных населенных пунктах в геохимических рядах присутствует U $($ КК $>1,5)$. Как и в случае с почвой, в накипи выделяется группа химических элементов $\mathrm{Au}$ полиметаллической ассоциации $(\mathrm{Zn}, \mathrm{Au}, \mathrm{Ba})$, в 4 населенных пунктах добавляется $\mathrm{Sb}$, в одном случае (г. Борзя) - As. Лишь в пробах из с. Уровские Ключи в геохимическом ряду нет $\mathrm{Sb}$ и As.

Отношение $\mathrm{Ca} / \mathrm{Ba}$ в накипи колеблется от 1714 (с. Тайна) до 24615 (с. Ямкун), отношения $\mathrm{La} / \mathrm{Yb}$ и La/Th весьма контрастны - минимальные значения составляют 1,5 и 2,3 (оба - с. Нерчинский Завод), максимальные - 532 (с. Ямкун) и 798 (с. Калга), соответственно. Br/U отношение характеризуется значениями от 0,003 до 1 , при этом наименьшее значение отмечено в с. Калга. По величине $\mathrm{Th} / \mathrm{U}$ отношения солевые образования питьевых вод имеют ярко выра- женную урановую природу: во всех случаях оно значительно меньше 1, минимума оно достигает в пробах с. Ямкун (0,00002).

Листья тополя являются природным геохимическим планшетом, который начинает активно использоваться в эколого-геохимических исследованиях [37-39]. Несмотря на короткий период (май-сентябрь) депонирования загрязняющих веществ, они являются хорошим материалом для исследования. В них накапливаются 5-7 химических элементов (с КК>1,5), указывающих, прежде всего, на биогеохимическую специфику самих листьев (Zn) и металлогеническую специализацию региона (Ba, Sb, As) за исключением $\mathrm{Au}$, которое не успевает накапливаться за короткий вегетационный период. Са и $\mathrm{Sr}$ накапливаются в вышекларковых содержаниях во всех населенных пунктах, кроме с. Нерчинский Завод. Из других особенностей стоит отметить накопление $\mathrm{Rb}$ в пробе из с. Ямкун, редких и редкоземельных элементов - в с. Газимурский Завод. Данные особенности подчеркивают гипотезу о петрогенной природе данных элементов.

Что касается индикаторных отношений, то отношение $\mathrm{Ca} / \mathrm{Sr}$ колеблется в интервале от 108 (с. Газимурский Завод) до 2206 (с. Нерчинский Завод), значение $\mathrm{Ca} / \mathrm{Ba}$ отношения - от 524 (с. Газимурский Завод) до 2068 (с. Горный Зерентуй). Отношение La/Yb слабо дифференцировано: от 8,7 (с. Тайна) до 32 (с. Ямкун). Такими же интервалами характеризуется $\mathrm{Br} / \mathrm{U}$ отношение - от 4,1 до 39. La/Th отношение также слабо дифференцировано (от 2,9 до 4,5). В большинстве населенных пунктов величина $\mathrm{Th} / \mathrm{U}$ отношения меньше 1 , только в с. Газимурский Завод оно существенно выше $1-3,9$.

Годовые кольиа деревьев являются индикатором поступления химических элементов во время роста дерева $[40,41]$, что позволяет использовать их в эколого-геохимических исследованиях $[42,43]$. В данном исследовании нам было важно оценить уровни накопления химических элементов во временном интервале и провести сравнительный анализ с другими районами (Горный Алтай). В данном случае мы обсуждаем геохимические особенности дерева (лиственница) по совокупности годовых колец, входящих в один временной срез.

Сравнение кларков концентраций химических элементов в годовых кольцах лиственницы, произрастающих в регионах, различных в геологическом отношении (Алтай, Забайкалье), показывает, что пробы с Алтая обогащены $\mathrm{Br}$, As и Co, а для проб из Забайкалья характерна $\mathrm{Au}-\mathrm{Ba}-\mathrm{Sr}$ специализация $($ КК>50). Также существенно накопление Са (КК 10). В распределении $\mathrm{Ca}, \mathrm{Fe}, \mathrm{Zn}, \mathrm{Br}, \mathrm{Nd}$ отмечается некоторая цикличность: так, в годовых кольцах (1946-1969 гг., 2000-2017 гг.) содержания этих элементов максимальны, в то время как в пробах с 1970 по 1999 гг. уровни накопления меньше. При этом $\mathrm{Ca} / \mathrm{Sr}$ изменяется от 25 (1946 г.) до 48 (2017 г.). Этот факт связан, возможно, с фазами атмосферного увлажнения, что требует дальнейших исследований и отдельного анализа. 
При рассмотрении индикаторных отношений необходимо отметить близкие значения $\mathrm{Ca} / \mathrm{Sr}$ отношения в лиственнице из населенных пунктов Забайкалья, тогда как $\mathrm{Ca} / \mathrm{Ba}$ отношение дифференцировано: минимальное значение отмечено в пробе из с. Тайна (37). Отношения $\mathrm{La} / \mathrm{Yb}, \mathrm{La} / \mathrm{Th}, \mathrm{Br} / \mathrm{U}$ минимальны в с. Уровские Ключи - 2, 0,7 и 17, соответственно. Th/U отношение во всех случаях меньше 1 .

Лишайники являются количественными индикаторами состояния окружающей среды, поскольку получают влагу из осадков или атмосферы, используя осмотическое давление. Это значит, что они поглощают все вещества из окружающей среды, не обладая механизмами освобождения от них $[3,44,45]$. В процессе выполнения работ нами производился отбор двух видов эпифитных лишайников: Evernia prunastri (L.) Ach. (1810) и Flavoparmelia caperata (Lobaria caperata (L.) Hoffm. (1796)).

Анализ геохимических особенностей этих видов позволяет сделать вывод, что оба вида обладают близкими концентрационными способностями и в дальнейшем рассматриваются нами без разделения.

Для лишайников изученных районов характерен низкий уровень концентрирования химических элементов относительно кларка ноосферы. Так, в геохимических рядах проб из с. Уровские Ключи и Калга отмечается только 1 элемент с КК>1,5 - Аu. Максимальное количество (6) выявлено в образцах из c. Тайна с $\mathrm{Ba}-\mathrm{Sb}-\mathrm{As}-\mathrm{Zn}$ ассоциацией $\mathrm{Au}$ полиметаллических месторождений. Такая же ассоциация выделена в с. Горный Зерентуй, вблизи которого с XVIII в. разрабатывалось Agполиметаллическое месторождение. При этом концентрация $\mathrm{Ag}$ в лишайниках оказалась ниже 0,3 г/т.

Максимальные значения $\mathrm{Ca} / \mathrm{Sr}$ (446) и $\mathrm{Ca} / \mathrm{Ba}(586)$ отношений установлены в пробах из с. Уровские Ключи, минимальные - в с. Тайна, 111 и 56, соответственно. Весьма интересно распределение $\mathrm{La} / \mathrm{Yb}$ отношения: оно минимально в с. Тайна - 9, максимально в с. Калга - 58, в других населенных пунктах оно колеблется незначительно (от 11 до 15). Разброс значений $\mathrm{La} / \mathrm{Yb}$ отношений составляет от 2,5 (с. Тайна) до 13 (с. Калга). Br/U отношение также максимально в пробах из с. Калга $(8,7)$, при этом минимальное значение отмечено в с. Ямкун (2). В двух из пяти населенных пунктов отношение $\mathrm{Th} / \mathrm{U}$ выше 1 и достигает 1,9 в с. Тайна, минимальное отношение отмечено в с. Калга $(0,1)$.

$M x u$ различных видов активно используются при биогеохимических поисках месторождений полезных ископаемых и в комплексном экологическом мониторинге. Данные по содержанию химических элементов во мхах отражают интегральное осаждение и накопление из воздуха и атмосферных осадков $[3,44,45]$. Для данного исследования был выбран мох кукушкин лен, или политрих обыкновенный (Polytrichum commune).

Геохимические особенности показывают, что пробы мха во всех шести изученных населенных пунктах характеризуются различными геохимическими рядами. Максимальное количество химических элементов с КК $>1,5$ отмечено в пробе из с. Ямкун, где отчетливо выделяется $\mathrm{Au}-\mathrm{Ab}-\mathrm{As}-\mathrm{Sb}$ ассоциация, характерная для данного района. Кроме того, только для этого населенного пункта в геохимическом ряду присутствует U. В других населенных пунктах к основной ассоциации в геохимических рядах добавляется $\mathrm{Zn}$ (с. Тайна, Горный Зерентуй). Минимальное количество (3) химических элементов с КК>1,5 отмечено в с. Уровские Ключи и Калга. Sr с КК>1,5 выявлен в пробах из с. Калга и Ямкун. Са в геохимических рядах нигде не зафиксирован.

Индикаторные отношения показывают разнонаправленную динамику. $\mathrm{Ca} / \mathrm{Sr}$ отношение максимально в с. Тайна (224), минимально в с. Калга (13), при этом в других населенных пунктах эти показатели близки (от 106 до 132). Аналогичную картину проявляет отношение $\mathrm{Ca} / \mathrm{Ba}$ : максимум (89) и минимум (29) отмечен в тех же населенных пунктах. Отношения $\mathrm{La} / \mathrm{Yb}$, $\mathrm{La} / \mathrm{Th}, \mathrm{Br} / \mathrm{U}$ и Th/U слабо дифференцированы: низкие значения $\mathrm{La} / \mathrm{Yb}$ отношения выявлены в с. Горный Зерентуй и Ямкун - 11 и 12, соответственно, при этом высокие значения данного показателя в с. Калга (18). $\mathrm{La} / \mathrm{Th}$ отношение минимально в с. Калга $(2,7)$ и максимально в с. Уровские Ключи (4). Минимальные значения $\mathrm{Br} / \mathrm{U}$ и $\mathrm{Th} / \mathrm{U}$ отношений отмечены в с. Ямкун (0,7 и 0,3 , соответственно), а максимальные - в с. Калга ( 3,4 и 2 , соответственно).

Польнь горькая (Artemísia absinthium) достаточно редкий объект для использования в экологогеохимических исследованиях, при этом обычно изучается наземная и корневая часть по отдельности $[46,47]$. На этапе отбора проб мы следовали этой же практике, однако после получения аналитических данных отказались от рассмотрения результатов по надземной части, поскольку в ней происходит концентрирование незначительного спектра химических элементов. Для сравнения, в надземной части накапливается от 1 до 5 химических элементов с КК $>1,5$, в то время как в корневой части отмечается от 10 до 19.

Особое внимание обращает на себя проба из с. Тайна, где в геохимическом ряду зафиксировано 19 из 25 изученных элементов, в том числе $\mathrm{Ba}-\mathrm{Sb}-\mathrm{As}-\mathrm{Au}-$ $\mathrm{Zn}$ ассоциация, характерная для региона и выявляемая практически во всех изученных компонентах. Из интересного также необходимо отметить следующие особенности: 1) накопление $\mathrm{Br}$ в надземной части растения по сравнению с корневой в пробах из н.п. Тайна, Уровские Ключи, Ямкун; 2) накопление Ag в надземной части образцов из с. Горный Зерентуй, что не согласуется с предположением о его концентрировании в корневой части в районе расположения Agполиметаллического рудного поля; 3) активное концентрирование редкоземельных элементов, Th и U в ряде проб. Са и $\mathrm{Sr}$ в некоторых пробах присутствуют в вышекларковых значениях.

Отношения химических элементов ведут себя разнонаправленно. Максимальные амплитуды отмечены для $\mathrm{Ca} / \mathrm{Sr}$ и $\mathrm{Ca} / \mathrm{Ba}$ : первый показатель варьирует от 33 (с. Нерчинский Завод) до 475 (с. Горный Зерентуй), второй - от 14 (с. Тайна) до 94 (с. Шелопугино). В то время как отношения $\mathrm{La} / \mathrm{Yb}, \mathrm{La} / \mathrm{Th}, \mathrm{Br} / \mathrm{U}$ и Th/U слабо дифференцированы: La/Yb - от 10 (с. Ямкун) до 17 
(с. Нерчинский Завод), La/Th - от 2,8 (с. Шелопугино) до 3,4 (с. Уровские Ключи, Горный Зерентуй), $\mathrm{Br} / \mathrm{U}-$ от 0,4 (с. Горный Зерентуй) до 6,9 (с. Ямкун), Th/U от 0,9 (с. Ямкун) до 3 (с. Горный Зерентуй).

Картофель не является первоочередным объектом при проведении эколого-геохимических исследований, однако в случае, когда необходимо оценить воздействие геохимического фактора на человека, изучение качества продуктов питания, в частности, картофеля, является хорошим способом получения информации о поступлении химических элементов в организм $[48,49]$.

Анализ данных показывает, что в силу специфики своего развития (короткий период вегетации) в клубнях картофеля накапливается небольшой (3-4) спектр химических элементов с КК $>1,5$. Выделяется сокращенная ассоциация $\mathrm{Au}-\mathrm{Zn}$, к которой иногда добавляется Ва (с. Калга). Во всех населенных пунктах в геохимическом ряду отмечается $\mathrm{Sr}$ при отсутствии $\mathrm{Ca}$. $\mathrm{B}$ пробе из с. Тайна появляется $\mathrm{Rb}$.

При изучении индикаторных отношений обращает на себя внимание следующий факт: 4 из 6 показателей $(\mathrm{Ca} / \mathrm{Sr}-104, \mathrm{Ca} / \mathrm{Ba}-469, \mathrm{La} / \mathrm{Th}-11, \mathrm{Br} / \mathrm{U}-28)$ принимают максимальное значение в пробах из с. Тайна, в то время как два других показателя $(\mathrm{La} / \mathrm{Yb}-$ $3,1, \mathrm{Th} / \mathrm{U}$ - 0,02) характеризуются минимальными значениями. Согласно литературным данным, уровень заболеваемости БКБ в данном населенном пункте составлял до 38 \%. Обратная картина наблюдается для с. Калга, которое считается фоновым по уровню заболеваемости БКБ.

Волосы детей за последние десятилетия стали объектом эколого-геохимического мониторинга, по их элементному составу накопилось большое количество данных. На сегодняшний день по Забайкальскому краю имеется значительный объем информации [50].

Анализ КК относительно регионального фона показывает, что максимальное накопление наблюдается в с. Калга ( $\mathrm{Na}, \mathrm{Sc}, \mathrm{Cr}, \mathrm{Fe}, \mathrm{Zn}, \mathrm{Br}, \mathrm{Rb}, \mathrm{Sb}, \mathrm{Eu}, \mathrm{Tb}, \mathrm{U})$, в с. Тайна концентрируются $\mathrm{Na}, \mathrm{Ca}, \mathrm{Br}, \mathrm{Rb}, \mathrm{Ag}, \mathrm{Cs}, \mathrm{Ba}, \mathrm{Ta}$, в с. Уровские Ключи - Na, As, Sb, Rb, Ag, Ta, в с. Нерчинский Завод - только Ag. Содержание $\mathrm{Sr}$ во всех пробах из данных населенных пунктов ниже регионального фона.

Геохимический ряд химических элементов, определенных методом ИСП-МС, выглядит урезано: в волосах накапливается от 2 (с. Калга) до 5 (с. Уровские Ключи, Тайна, Нерчинский Завод) элементов с КК $>1,5$, преимущественным элементом является $\mathrm{Bi}$, который в других изученных компонентах ранее не встречался. При этом необходимо отметить, что повышенное содержание Ві отмечалось и в населенных пунктах, подверженных БКБ в Китае [51]. Во всех населенных пунктах отмечается $\mathrm{Zn}$, в н.п. Тайна и Уровские Ключи $-\mathrm{Cd}$, в с. Нерчинский Завод и Уровские Ключи - Se. Для волос из с. Калга отмечено избыточное количество Au. Полученные данные для ряда химических элементов коррелируют с данными по Китаю [52].
В связи с тем, что волосы были проанализированы методом ИСП-МС, спектр отношений химических элементов был расширен за счет $\mathrm{Ca} / \mathrm{Mn}, \mathrm{P} / \mathrm{Mn}$ и $\mathrm{Ca} / \mathrm{P}$, которые в научной литературе рассматриваются как индикаторные для районов проявления БКБ. Максимальные значения отношений $\mathrm{Ca} / \mathrm{Sr}$ (355), $\mathrm{Ca} / \mathrm{Ba}(384))$ и $\mathrm{Ca} / \mathrm{Mn}$ (227) отмечены в пробах из с. Тайна, минимальные значения наблюдаются в образцах из с. Уровские Ключи (71 и 70, соответственно). Самые высокие $(9,6)$ и низкие $(0,8)$ показатели $\mathrm{Ca} / \mathrm{P}$ отношения зафиксированы в н.п. Тайна и Уровские Ключи, соответственно, которые характеризуются как территории проявления БКБ. $\mathrm{La} / \mathrm{Yb}$ колеблется от 1,8 (с. Нерчинский Завод) до 6,1 (с. Тайна), La/Th - от 0,9 (с. Калга, Нерчинский Завод) до 5,1 (с. Уровские Ключи), $\mathrm{Br} / \mathrm{U}$ - от 15 (с. Калга) до 128 (с. Тайна), $\mathrm{Th} / \mathrm{U}$ - от 0,02 (н.п. Калга и Нерчинский Завод) до 0,08 (с. Уровские Ключи).

Кость свиньи домашней - новый объект, который может быть использован в эколого-геохимических исследованиях, поскольку организм свиньи домашней (Sus scrofa domesticus) наиболее близок к организму человека по физиологическим параметрам и особенностям питания. Ранее проведенные нами исследования показали практически полное совпадение элементного состава органов и тканей организма данного вида и организма человека на одной территории [53]. Поэтому использование данного вида в качестве модельного может служить достаточно надежным индикатором при оценке воздействия факторов окружающей среды на организм человека [53-55], что особенно актуально при изучении эндемических болезней, таких как БКБ. Следует отметить, что при анализе литературы по особенностям проявления БКБ часто обращалось внимание на высокую ломкость костей у животных [56, 57 и др.]. В нашем исследовании были изучены пробы берцовой кости свиньи, которые были отобраны у местного населения. При подготовке к аналитическим исследованиям одной из проб, взятой в с. Уровские Ключи, обнаружился физический дефект кортикальной части с ярко выраженной секвестральной полостью $(25 * 10$ мм), краевые части которой были сложены истонченной тканью с легко отделяющимися осколками (рис. 3). В данном случае для изучения было подготовлено 2 пробы: первая - из малой берцовой кости, вторая была представлена осколками из секвестральной полости большой берцовой кости.

Из геохимических особенностей стоит отметить следующее: максимальные концентрации 36 из 66 определенных методом ИСП-МС химических элементов зафиксировано в пробе из с. Калга - населенном пункте, где БКБ практически не фиксировалась, в список этих элементов входят $\mathrm{Li}, \mathrm{Zn}, \mathrm{Ge}, \mathrm{Cd}, \mathrm{Nd}, \mathrm{W}$, $\mathrm{Hg}, \mathrm{Tl}, \mathrm{Bi}, \mathrm{Th}, \mathrm{U}$; максимальные содержания 12 химических элементов отмечены в образце из с. Газимурский Завод, в том числе $\mathrm{Na}, \mathrm{P}, \mathrm{K}, \mathrm{Ca}, \mathrm{Cr}, \mathrm{As}, \mathrm{Sb}, \mathrm{Te}$, $\mathrm{Ba}, \mathrm{Au}, \mathrm{Pb} . \mathrm{B}$ свою очередь в пробе из с. Уровские Ключи наибольшие концентрации выявлены только для $\mathrm{Ag}$ (в малой берцовой кости), $\mathrm{Ru}, \mathrm{In}, \mathrm{Re}$ (в патологически измененной большой берцовой кости). 
Анализ геохимических рядов относительно кларка ноосферы показывает, что Р занимает ведущую позицию в ряду во всех населенных пунктах, что объясняется составом кости - матричная основа состоит из $\mathrm{Ca}$ (от 20,5 \% в условной здоровой кости из с. Уровские Ключи до 26 \% в образце из с. Газимурский Завод) и Р (от $10,3 \%$ в условной здоровой кости из с. Уровские Ключи до 12,9 \% в пробе из с. Тайна). Аs и $\mathrm{Au}$ также занимают ведущие позиции в геохимических рядах, при этом в патологически измененной кости в ряду отсутствует As. Во всех геохимических рядах также присутствуют $\mathrm{Sr}$ и $\mathrm{Zn}$, что, вероятно, указывает на их роль как компонента костной ткани. Из других интересных особенностей стоит отметить наличие Вi (кроме с. Тайна), Hg (кроме патологически измененной кости), $\mathrm{Cr}$ (только в с. Калга). В свою очередь, лишь в патологически измененной кости отмечено накопление $\operatorname{Re}(\mathrm{KK}-17)$.

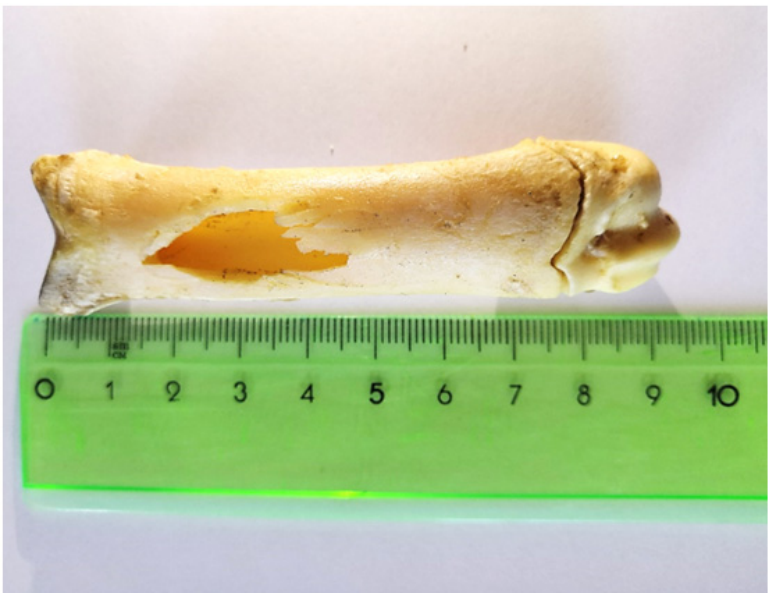

Рис. 3. Секвестральная полость на большой бериовой кости свиньи домашней, с. Уровские Ключи (сентябрь 2017 г.)

Fig. 3. Sequestral cavity in tibia of domestic pig, Urovskie Klyuchi village (September, 2017)

Индикаторные отношения также дают интересную информацию. Отношение $\mathrm{Ca} / \mathrm{Sr}$ варьирует от 669 (с. Калга) до 2268 (с. Тайна), при этом данный показатель в условно здоровой и патологически измененной кости примерно одинаков (1147 и 1314, соответственно). Интервал $\mathrm{Ca} / \mathrm{Ba}$ отношения составляет от 8142 (с. Калга) до 20787 (с. Тайна), данные по условно здоровой и патологически измененной кости также примерно схожи (15866 и 15007). Для $\mathrm{Ca} / \mathrm{Mn}$ и $\mathrm{P} / \mathrm{Mn}$ минимальное значение установлено также в пробе из с. Калга (9917 и 4165), а вот максимальное отмечено в патологически измененной кости из с. Уровские Ключи (169928 и 76982), в то время как в условной здоровой данные показатели составляют 18305 и 9321 Важный в целом для кости параметр $\mathrm{Ca} / \mathrm{P}$ изменяется в узком интервале $(2,0-2,2)$, что близко к данным по зольному остатку организма человека $[58,59]$. Остальные отношения также показывают разнонаправленную динамику: $\mathrm{La} / \mathrm{Yb}$ - от 3 (патологически измененная кость) и 13 (условно здоровая кость) в с. Уровские Ключи до 63 (с. Газимурский Завод);
$\mathrm{La} / \mathrm{Th}$ - от 1,7 (патологически измененная кость в с. Уровские Ключи) до 3,1 (с. Тайна); $\mathrm{Br} / \mathrm{U}$ - от 0,8 (условно здоровая кость) и 1,2 (патологически измененная кость и проба из с. Тайна) до 5 (с. Газимурский Завод); Th/U изменяется в незначительных пределах $(1,5-3,1)$, при этом наиболее контрастно данный показатель смотрится при сравнении условно здоровой $(\mathrm{Th} / \mathrm{U}-3,0)$ и патологически измененной $(\mathrm{Th} / \mathrm{U}-0,3)$ костей.

В целом, как показывают полученные данные, кость свиньи домашней может выступать интересным индикатором при сравнительном геохимическом анализе различных населенных пунктов, особенно с проявлениями заболеваний опорно-двигательного аппарата.

Проведенный анализ геохимических особенностей компонентов природной среды в районе проявления БКБ показывает их разнообразие как по уровням накопления химических элементов, так и по отношению химических элементов в различных населенных пунктах. Нами предпринята попытка определить геохимическую специализацию компонента природной среды в зависимости от места отбора для трех населенных пунктов, где были отобраны все изучаемые компоненты: Калга, Тайна, Уровские Ключи. Компоненты были проранжированы по сумме мест, занимаемой по геохимическим показателям (от 4 до 10) в каждом населенном пункте. Чем меньше сумма, тем чаще населенный пункт занимает первые места по рассчитанным показателям (максимальное количество химических элементов с КК $>1,5$; максимальные значения индикаторных отношений). В результате был получен следующий ряд: с. Тайна (средняя сумма мест - 1,7) - с. Уровские Ключи $(2,0)$ - с. Калга (2,2) (табл. 3).

Как показывает анализ данных табл. 3, именно в с. Тайна выявлено наибольшее количество показателей с максимальными значениями. Следует отметить, что по литературным данным в данном населенном пункте уровень заболеваемости БКБ составлял 30,4 \% [31]. Калга во всех источниках рассматривается как населенный пункт, благоприятный по БКБ [4 и др.], при этом средняя сумма ранжированных показателей максимальна среди рассматриваемых населенных пунктов. Несмотря на то, что Уровские Ключи находятся в эпицентре распространения БКБ, в нем не фиксировалось значимого проявления заболевания, что связано с расположением села в поле развития карбонатных пород кембрийского возраста [30, 60-62], как результат в почве, воде и других средах наблюдается избыток Са. Это подтверждается и нашими данными.

Полученные данные свидетельствуют о том, что БКБ полиэтиологична: большую роль играют природные условия (низкие температуры, развитие мерзлотных лугово-болотных ландшафтов), это подтверждается последними данными китайских ученых [63]. В основе болезни лежит несбалансированность элементного состава компонентов природной среды, как следствие, дисбаланс в химическом составе продуктов питания, питьевой воды, что приводит к недостатку/избытку химических элементов в организме местных жителей. Индикаторы биогеохимической 
природы БКБ остаются дискуссионными. Возникновение болезни нельзя связывать только лишь с одним химическом элементом, видимо, в данном случае проявляется синергетический эффект [64-67].

Таблица 3. Геохимические особенности компонентов природной среды в исследованных населенных пунктах

Table 3. Geochemical features of the environmental components in the investigated settlements

\begin{tabular}{|c|c|c|c|}
\hline \multirow{2}{*}{$\begin{array}{l}\text { Компонент природной среды } \\
\text { Environmental component }\end{array}$} & \multicolumn{3}{|c|}{ Населенные пункты/Settlements } \\
\hline & Тайна/Taina & Уровские Ключи/Urovskie Klyuchi & Калга/Kalga \\
\hline Почва/Soil & $\mathrm{Ca} / \mathrm{Sr}, \mathrm{Br} / \mathrm{U}$ & $\mathrm{N}, \mathrm{Ca} / \mathrm{Ba}, \mathrm{La} / \mathrm{Yb}, \mathrm{Th} / \mathrm{U}$ & $\mathrm{La} / \mathrm{Th}$ \\
\hline $\begin{array}{l}\text { Донные отложения } \\
\text { Bottom sediments }\end{array}$ & $\mathrm{Ca} / \mathrm{Sr}, \mathrm{Ca} / \mathrm{Ba}, \mathrm{La} / \mathrm{Yb}, \mathrm{La} / \mathrm{Th}$ & $\mathrm{Ca} / \mathrm{Mn}$ & $\mathrm{N}, \mathrm{Th} / \mathrm{U}$ \\
\hline $\begin{array}{l}\text { Подземные воды } \\
\text { Underground waters }\end{array}$ & $\mathrm{N}$ & $\mathrm{Ca} / \mathrm{Sr}, \mathrm{Ca} / \mathrm{Ba}$ & $\mathrm{Ca} / \mathrm{Mn}$ \\
\hline $\begin{array}{l}\text { Поверхностные воды } \\
\text { Surface waters }\end{array}$ & $\mathrm{N}$ & & $\mathrm{Ca} / \mathrm{Sr}, \mathrm{Ca} / \mathrm{Ba}, \mathrm{Ca} / \mathrm{Mn}$ \\
\hline $\begin{array}{l}\text { Солевые отложения питьевых вод } \\
\text { Drinking water salt sediments }\end{array}$ & $\mathrm{N}, \mathrm{La} / \mathrm{Yb}, \mathrm{Br} / \mathrm{U}, \mathrm{Th} / \mathrm{U}$ & $\mathrm{Ca} / \mathrm{Sr}, \mathrm{Ca} / \mathrm{Ba}$ & $\mathrm{N}, \mathrm{La} / \mathrm{Th}$ \\
\hline $\begin{array}{l}\text { Керн годовых колец деревьев } \\
\text { Core of tree rings }\end{array}$ & $\mathrm{N}, \mathrm{La} / \mathrm{Yb}, \mathrm{La} / \mathrm{Th}, \mathrm{Br} / \mathrm{U}$ & $\mathrm{Ca} / \mathrm{Sr}, \mathrm{Ca} / \mathrm{Ba}, \mathrm{Th} / \mathrm{U}$ & \\
\hline Листья тополя/Poplar leaves & $\mathrm{N}$ & $\mathrm{Ca} / \mathrm{Sr}, \mathrm{Ca} / \mathrm{Ba}, \mathrm{La} / \mathrm{Th}$ & $\mathrm{La} / \mathrm{Yb}, \mathrm{La} / \mathrm{Th}, \mathrm{Br} / \mathrm{U}, \mathrm{Th} / \mathrm{U}$ \\
\hline Лишайник/Lichen & $\mathrm{N}, \mathrm{Th} / \mathrm{U}$ & $\mathrm{Ca} / \mathrm{Sr}, \mathrm{Ca} / \mathrm{Ba}$ & $\mathrm{La} / \mathrm{Yb}, \mathrm{La} / \mathrm{Th}, \mathrm{Br} / \mathrm{U}$ \\
\hline Mox/Moss & $\mathrm{N}, \mathrm{Ca} / \mathrm{Sr}, \mathrm{Ca} / \mathrm{Ba}$ & $\mathrm{La} / \mathrm{Th}$ & $\mathrm{La} / \mathrm{Yb}, \mathrm{Br} / \mathrm{U}, \mathrm{Th} / \mathrm{U}$ \\
\hline Полынь/Wormwood & $\mathrm{N}, \mathrm{Br} / \mathrm{U}, \mathrm{Th} / \mathrm{U}$ & $\mathrm{Ca} / \mathrm{Sr}, \mathrm{Ca} / \mathrm{Ba}, \mathrm{La} / \mathrm{Yb}, \mathrm{La} / \mathrm{Th}$ & \\
\hline Картофель/Potato & $\mathrm{N}, \mathrm{Ca} / \mathrm{Sr}, \mathrm{Ca} / \mathrm{Ba}, \mathrm{La} / \mathrm{Th}, \mathrm{Br} / \mathrm{U}$ & $\mathrm{La} / \mathrm{Yb}, \mathrm{Th} / \mathrm{U}$ & $\mathrm{N}$ \\
\hline Волосы детей/Children's hair & $\begin{array}{c}\mathrm{N}, \mathrm{Ca} / \mathrm{Sr}, \mathrm{Ca} / \mathrm{Ba}, \mathrm{La} / \mathrm{Yb}, \mathrm{Br} / \mathrm{U}, \\
\mathrm{Ca} / \mathrm{Mn}, \mathrm{Ca} / \mathrm{P}\end{array}$ & $\mathrm{N}, \mathrm{P} / \mathrm{Mn}, \mathrm{La} / \mathrm{Th}, \mathrm{Th} / \mathrm{U}$ & \\
\hline $\begin{array}{l}\text { Кости свиньи домашней } \\
\text { Bone of domestic pig }\end{array}$ & $\begin{array}{c}\mathrm{Ca} / \mathrm{Sr}, \mathrm{Ca} / \mathrm{Ba}, \mathrm{La} / \mathrm{Th}, \mathrm{Ca} / \mathrm{Mn}, \\
\mathrm{Ca} / \mathrm{P}, \mathrm{P} / \mathrm{Mn}\end{array}$ & $\mathrm{Br} / \mathrm{U}, \mathrm{Th} / \mathrm{U}$ & \\
\hline
\end{tabular}

Примечание: $N$ - максимальное количество химических элементов с коэффициентом концентрации больше 1,5; 8 таблице отражены индикаторные отношения, значения которых максимальны в определенном населенном пункте.

Note: $N$ - maximum list of chemical elements with concentration coefficient more than 1,5; in the table we represent indicative ratios that take the leading positions in a given settlement.

\section{Заключение}

Район распространения БКБ в Забайкальском крае расположен в весьма сложном по геологическим и металлогеническим особенностям блоке земной коры, что приводит к формированию сложных геохимических обстановок и ассоциаций в компонентах природной среды. Вероятно, ландшафтногеоморфологические, гидрогеологические, геохимические и некоторые другие факторы могут быть одной из причин развития БКБ. Нельзя отрицать и их сочетанное (синергетическое) воздействие.

Геохимические особенности изученных компонентов природной среды свидетельствуют, что многие из ранее высказанных геохимических гипотез $(\mathrm{Ca} / \mathrm{P}, \mathrm{Ca} / \mathrm{Sr}, \mathrm{P} / \mathrm{Mn}$, коллоидное золото, радиоактивность) находят то или иное подтверждение. В компонентах природной среды выделяется сквозная региональная геохимическая ассоциация ( $\mathrm{Zn}-\mathrm{Pb}-\mathrm{Ba}-\mathrm{Sb}-\mathrm{As}-$ $\mathrm{Bi}-\mathrm{Au})$ с вариациями в зависимости от объекта исследования. Данная ассоциация отражает особенности общей металлогении района.

Для проведения исследований в данном районе наиболее информативными компонентами являются природные воды, костная ткань, волосы детей Остальные компоненты могут быть выбраны по усмотрению исследователей. Среди геохимических

\section{СПИСОК ЛИТЕРАТУРЫ}

1. Справочник по геохимическим поискам полезных ископаемых / под ред. А.П. Соловова. - М.: Недра, 1990. - 335 с.

2. Химический анализ в геологии и геохимии / под ред. Г.Н. Аношина. - Новосибирск: Академическое издательство «Гео», 2016. - $622 \mathrm{c}$. показателей должны оцениваться уровни накопления $\mathrm{Ca}, \mathrm{P}, \mathrm{Mn}, \mathrm{Sr}, \mathrm{Ba}, \mathrm{Br}, \mathrm{U}, \mathrm{Th}, \mathrm{La}, \mathrm{Yb}$. Для получения полной картины по F и Se необходимо применять более чувствительные аналитические методы.

Наиболее контрастная геохимическая специфика формируется в населенных пунктах, где по литературным данным наблюдались максимальные уровни заболеваемости БКБ. К таковым из изученных населенных пунктов относится с. Тайна.

В районе проявления БКБ на юго-востоке Забайкальского края формируется сложная геохимическая обстановка, обусловленная сочетанным воздействием ряда природных факторов. Необходимость оценки влияния (возможно, как положительного, так и отрицательного) данных факторов является научной и прикладной задачей ввиду активного горнопромышленного освоения территории проявления БКБ в Забайкальском крае.

Научные исследования выполнены в рамках программы повышения конкурентоспособности ТПУ среди ведущих мировых исследовательских иентров. Анализ проб методом ICP-MS выполнен при финансовой поддержке РФФИ (проект № 19-35-90061). Обработка данных и интерпретация результатов выполнена в рамках реализации гранта Российского научного фонда (проект № 20-64- 47021).

3. Биогеохимический мониторинг в районах хвостохранилищ горнодобывающих предприятий с учетом микробиологических факторов трансформации минеральных компонентов / Л.П. Рихванов, Н.А. Абросимова, Н.В. Барановская, Т.С. Большунова, Е.А. Горбатюк, А.В. Еделев, А.М. Межибор, И.Н. Мягкая, Б.Р. Соктоев, Д.В. Юсупов, Л.Н. Белан, 
С.Б. Бортникова, М.А. Густайтис, С.М. Жмодик, Н.В. Ищук, И.С. Кириченко, Д.В. Наркович, Е.В. Лазарева, В.В, Оленченко, О.П. Саева, Б.Ю. Сарыг-оол, Т.В. Усманова, Н.В. Юркевич. - Новосибирск: Изд-во СО РАН, 2017. - 437 с

4. Дамперов Н.И. Карта распространения уровской болезни // Уровская болезнь в Забайкалье. - Иркутск, 1934. - С. 15-23.

5. Х Хачумова К.Г., Лыткина К.А., Ильина Е.Ю. Болезнь КашинаБека: диагностика, дифференциальный диагноз // Вестник Российского государственного медицинского университета. 2010. - № 6. - C. 15-19.

6. Allander E. Kashin-Beck disease. An analysis of research and public health activities based on a bibliography 1849-1992 // Scandinavian Journal of Rheumatology. - 1994. - V. 23. - P. 1-36.

7. Yamamuro T. Kashin-Beck disease: a historical overview // International Orthopaedics. - 2001. - V. 25. - P. 134-137.

8. Stone R. A medical mystery in middle China // Science. - 2009. V. 324. - P. 1378-1381

9. Big bone disease: a multidisciplinary approach of Kashin-Beck disease in Tibet Autonomous Region (P.R. China) / Eds. F. Malaisse, F. Mathieu. - Gembloux: Les Presses Agronomiques de Gembloux, 2008. - 148 p.

10. Иванова М.А., Иванова О.М. Новые медицинские технологии в исследовании болезни Кашина-Бека и ХОБЛ // Вестник новых медицинских технологий. - 2017. - Т. 24. - № 4. - С. 209-218.

11. Endemic Kashin-Beck disease: A food-sourced osteoarthropathy K. Wang, J. Yu, H. Liu, Y. Liu, N. Liu, Y. Cao, X. Zhang, D. Sun / Seminars in Arthritis and Rheumatism. - 2020. - V. 50. - P. 366-372.

12. Государственная геологическая карта Российской Федерации Масштаб 1:1000000 (третье поколение). Лист М-50 - Борзя Объяснительная записка. - СПб.: Картографическая фабрика ВСЕГЕИ, 2010. - $553 \mathrm{c}$.

13. Guo X., Ning Y., Wang X. Selenium and Kashin-Beck disease // Selenium: chemistry, analysis, function and effects (food and nutritional components in focus) / Ed. by V.R. Preedy. Cambridge: Royal Society of Chemistry, 2015. - P. 552-571.

14. Du B., Zhou J., Zhou J. Selenium status of children in KashinBeck disease endemic areas in Shaanxi, China: assessment with mercury // Environmental Geochemistry and Health. - 2018. V. 40. - P. 903-913.

15. Associations between selenium content in hair and Kashin-Beck disease/Keshan disease in children in northwestern China: a prospective cohort study / H. Liu, F. Yu, W. Shao, D. Ding, Z. Yu, F. Chen, D., Geng X. Tan, M.J. Lammi, X. Guo // Biological Trace Element Research. - 2018. - V. 184. - P. 16-23.

16. Serious selenium deficiency in the serum of patients with KashinBeck disease and the effect of nano-selenium on their chondrocytes / L. Wang, J. Yin, B. Yang, C. Qu, J. Lei, J. Han, X. Guo // Biological Trace Element Research. - 2020. - V. 194. P. $96-104$

17. Аникина ЛІВ., Никитина Л.П. Селен. Экология, патология, коррекция. - Чита: ИИЦ ЧГМА, 2002. - 400 с.

18. Глазовская М.А. Геохимия природных и техногенных ландшафтов СССР. - М.: Высшая школа, 1988. - 328 с.

19. Vetrov V.A., Kuznetsova A.I., Sklyarova O.A. Baseline levels of chemical elements in the water of Lake Baikal // Geography and Natural Resources. - 2013. - V. 34. - P. 228-238.

20. Язиков Е.Г., Таловская А.В., Жорняк Л.В. Оценка экологогеохимического состояния территории г. Томска по данным изучения пылеаэрозолей и почв. - Томск: Изд-во ТПУ, 2010 - 264 с.

21. Pye K., Blott S.J. Comparison of soils and sediments using major and trace element data // Geological Society Special Publication. 2004. - V. 232. - P. 183-196.

22. He Z.L., Yang X.E., Stoffella P.J. Trace elements in agroecosystems and impacts on the environment // Journal of Trace Elements in Medicine and Biology. - 2005. - V. 19. P. $125-140$.

23. Watershed scale assessment of rare earth elements in soils derived from sedimentary rocks / B. de Albuquerque Pereira, Y.J.A.B. da Silva, C.W.A. do Nascimento, Y.J.A.B. da Silva, R.C. Nascimento, C.L. Boechat, R.S. Barbosa, V.P. Singh // Environmental Monitoring and Assessment. - 2019. - V. 191. - Article 514.

24. Alekseev A.O., Kalinin P.I., Alekseeva T.V. Soil indicators of paleoenvironmental conditions in the south of the East European Plain in the Quaternary time // Eurasian Soil Science. - 2019. V. 52. - P. 349-358.
25. Алексенцева Н.Н. Эколого-геохимические особенности территории Юго-Восточного Забайкалья, эндемичной по болезни Кашина-Бека: автореф. дис. ... канд. геол.-минерал. наук. Минск, 1987. - 20 с

26. Страховенко В.Д. Геохимия донных отложений малых континентальных озер Сибири: автореф. дис. ... докт. геол.-минерал. наук. - Новосибирск, 2011. - 33 с.

27. Иванов А.Ю. Экогеохимия донных отложений малых водоёмов юга Томской области: автореф. дис. ... канд. геол.минерал. наук. - Томск, 2018. - 22 с.

28. Heavy metals in surface sediments in the trans-Himalayan Koshi River catchment: distribution, source identification and pollution assessment / M. Li, Q. Zhang, X. Sun, K. Karki, C. Zeng, A. Pandey, B. Rawat, F. Zhang // Chemosphere. - 2020. - V. 244. Article 125410.

29. Новые данные об элементном составе природных вод в районе распространения уровской (Кашина-Бека) болезни (Забайкальский край) / Л.В. Замана, Л.П. Рихванов, Б.Р.., Соктоев Н.В. Барановская, Е.С. Эпова, М.А. Солодухина, Л.А. Михайлова, Ю.Г. Копылова, А.А. Хващевская // Известия Томского политехнического университета. Инжиниринг георесурсов. 2019. - T. 330. - № 1. - C. 121-133.

30. Виноградов А.П. Геохимические исследования в области распространения уровской эндемии // Доклады АН СССР. 1939. - Т. 23. - № 1. - С. 64-67.

31. К этиологии уровской (Кашина-Бека) болезни / А.В. Вощенко, В.Н. Чугаев, С.И. Вайстух, В.С. Бутко // Педиатрия: вопросы диагностики и лечения: тезисы докладов научнопрактической конференции. - Чита: Изд-во Читинской государственной медицинской академии, 1988. - С. 20-23.

32. Бутко В.С. Содержание и соотношение некоторых макро- и микроэлементов во внешней среде и тканях человека в районе уровской эндемии Восточного Забайкалья: автореф. дис. ... канд. биол. наук. - Чита, 1973. - 24 с.

33. Бутко В.С. Содержание некоторых микроэлементов в рационах жителей уровской эндемии // Вопросы медицинской экологии и проблемы улучшения здоровья населения Забайкалья и КНДР. - Чита: Изд-во Читинской государственной медицинской академии, 1989. - С. 79-80.

34. Минералого-геохимические особенности источника Ямкун (Забайкальский край) / Б.Р. Соктоев, Л.П. Рихванов, Н.В. Барановская, Л.В. Замана, М.А. Рудмин, Е.С. Эпова, М.А. Солодухина, К.А. Этенко, Л.А. Михайлова, И.В. Холмогорова // Известия Томского политехнического университета. Инжиниринг георесурсов. - 2019. - Т. 330. - № 7. - С. 140-154.

35. Evaluation of drinking water according to geochemical composition of its salt deposition / L. Rikhvanov, N. Baranovskaya, B. Soktoev, T. Mongolina $/ / 8^{\text {th }}$ International Conference on Environmental Engineering: proceedings. - Vilnius: Vilnius Gediminas Technical University Publishing House «Technika», 2011. - P. 337-342.

36. Soktoev B.R., Rikhvanov L.P., Matveenko I.A. Mineralogical and geochemical characteristics of drinking water salt deposits // IOP Conference Series: Earth and Environmental Science. - 2015. V. 27. - Article 012042.

37. Геохимические особенности элементного состава листьев тополя урбанизированных территорий / Д.В. Юсупов, Л.П. Рихванов, Н.В. Барановская, А.Р. Ялалтдинова // Известия Томского политехнического университета. Инжиниринг георесурсов. - 2016. - T. 327. - № 6. - C. 25-36.

38. Geochemical transformation of soil cover and woody vegetation in the largest industrial and transport center of Northern Mongolia (Darkhan) / N.E. Kosheleva, I.V. Timofeev, N.S. Kasimov, E.-A. Sandag // Applied Geochemistry. - 2019. - V. 107. P. $80-90$.

39. Rare earth elements in poplar leaves as indicators of geological environment and technogenesis / D.V. Yusupov, N.V. Baranovskaya, Y.V. Robertus, V.I. Radomskaya, L.M. Pavlova, A.F. Sudyko, L.P. Rikhvanov // Environmental Science and Pollution Research. 2020. - V. 27. - P. 27111-27123.

40. Баргальи Р. Биогеохимия наземных растений. - М.: ГЕОС, 2005. $-454 \mathrm{c}$

41. Рихванов Л.П., Архангельская Т.А., Замятина Ю.Л. Дендрорадиография как метод ретроспективной оценки радиоэкологической ситуации. - Томск: Изд-во ТПУ, 2015. - 148 с. 
42. Use of tree rings as a bioindicator to observe atmospheric heavy metal deposition / A. Turkyilmaz, H. Sevik, K. Isinkaralar, M. Cetin // Environmental Science and Pollution Research. 2019. - V. 26. - P. 5122-5130.

43. Eby N. The smelters and the tree - an environmental story // Geology Today. - 2020. - V. 36. - Iss. 2. - P. 59-63.

44. Investigation of spatial and temporal metal atmospheric deposition in France through lichen and moss bioaccumulation over one century / Y. Agnan, N. Séjalon-Delmas, A. Claustres, A. Probst / Science of the Total Environment. - 2015. - V. 529. - P. 285-296.

45. Malikova I.N., Strakhovenko V.D., Shcherbov B.L. Distribution of radionuclides in moss-lichen cover and needles on the same grounds of landscape-climatic zones of Siberia // Journal of Environmental Radioactivity. - 2019. - V. 198. - P. 64-78.

46. Kudrevatykh I.Y., Kalinin P.I., Alekseev A.O. Biogenic accumulation of chemical elements by plants of Genus Poaceae Barnhart and Genus Artemisia L. in the dry steppe and semidesert zones of the south of the Russian Plain // Contemporary Problems of Ecology. - 2019. - V. 12. - P. 377-385.

47. Pollution assessment of heavy metals in soils and plants around a molybdenum mine in central China / Z. Han, D. Wan, H. Tian, W. He, Z. Wang, Q. Liu // Polish Journal of Environmental Studies. - 2019. - V. 28. - P. 123-133.

48. Biological and geochemical markers of the geographical origin and genetic identity of potatoes / P. Adamo, M. Zampella, C.R. Quétel, R. Aversano, F. dal Piaz, N. de Tommasi, L. Frusciante, M. Iorizzo, L. Lepore, D. Carputo // Journal of Geochemical Exploration. - 2012. - V. 121. - P. 62-68.

49. Impact of the coal mining-contaminated soil on the food safety in Shaanxi, China / R. Hussain, K. Luo, H. Liang, X. Hong // Environmental Geochemistry and Health. - 2019. - V. 41. P. 1521-1544.

50. Влияние антропогенных геохимических факторов среды обитания на элементный статус детей п. Хапчеранга (Восточное Забайкалье) / Ю.А. Витковский, Л.А. Михайлова, Е.А. Бондаревич, М.А. Солодухина, Е.С. Эпова, О.В. Еремин, О.Г. Алексеева Н.М. Бурлака, С.Э. Лапа, Н.В. Барановская, Е.В. Агеева // Забайкальский медицинский вестник. - 2018. - № 2. - С. 14-23.

51. Hair multi-bioelement profile of Kashin-Beck disease in the endemic regions of China / X. Wang, Y. Ning, P. Zhang, C. Li, R. Zhou, X. Guo // Journal of Trace Elements in Medicine and Biology. - 2019. - V. 54. - P. 79-97.

52. Trace element levels in scalp hair of school children in Shigatse, Tibet, an endemic area for Kaschin-Beck disease (KBD) / Y. Guo, H. Li, L. Yang, Y. Li, B. Wei, W. Wang, H. Gong, M. Guo, C. Nima, S. Zhao, J. Wang // Biological Trace Element Research. - 2017. - V. 180. - P. 15-22.

53. Барановская Н.В., Рихванов Л.П. Элементный состав органов и тканей домашних животных (Sus scrofa domesticus (Artio dactila, Mammalia)) как индикатор среды обитания // Проблемы биогеохимии и геохимической экологии. - 2011. - № 3. C. $74-84$.
54. Элементный состав воды биологической как индикатор техногенеза / Л.П. Рихванов, Н.В., Барановская Н.П. Корогод, А.А. Хващевская, Ю.Г. Копылова, И.С. Мазурова, Р.Ж. Муканова, Т.К. Туркбенов, М.И. Скрипник, А.И. Баляновская // Известия Томского политехнического университета. Инжиниринг георесурсов. - 2019. - Т. 330. - № 2. - С. 214-223.

55. A regional approach for the calculation of characteristic toxicity factors using the USEtox model / A. Belyanovskaya, B. Laratte, N. Perry, N. Baranovskaya // Science of the Total Environment. 2019. - V. 655. - P. 676-683.

56. Уровская болезнь / К.П. Чепуров, А.В. Черкасова, Н.М. Акулов, И.И. Островский, Д.Ф. Мартынюк. - Благовещенск: Амурское книжное изд-во, 1955. - 199 с.

57. Рейнберг С.А. Рентгенодиагностика заболеваний костей и суставов. 4-е изд. - М.: Медицина, 1964. - Т. 1. -529 с.

58. Отражение среды обитания в минералогических особенностях зольного остатка организма человека / М.А. Дериглазова, Л.П. Рихванов, Н.В. Барановская, С.С. Ильенок // Вестник Забайкальского государственного университета. - 2019. T. 25. - № 10. - C. 6-14.

59. Skinner C.W. Mineralogy of bone // Essentials of medical geology. - Dordrecht: Springer, 2013. - P. 665-687.

60. Виноградов А.П. О причинах происхождения уровской эндемии (геохимические исследования) // Труды Биогеохимической лаборатории. - М.: Изд-во АН СССР, 1949. - Т. 9. - С. 5-29.

61. Biogeochemistry of calcium and strontium in the landscapes of Eastern Transbaikalia / V.V. Ermakov, U.A. Gulyaeva, S.F. Tyutikov, T.G. Kuz'mina, V.A. Safonov // Geochemistry International. - 2017. - V. 55. - P. 1105-1117.

62. Relationship of the mobile forms of calcium and strontium in soils with their accumulation in meadow plants in the area of KashinBeck endemia / V. Ermakov, J. Bech, U. Gulyaeva, S. Tyutikov, V. Safonov, V. Danilova, N. Roca // Environmental Geochemistry and Health. -2020 . - V. 42. - P. 159-171.

63. Zha X. Gao X. Ecological analysis of Kashin-Beck osteoarthropathy risk factors in Tibet's Qamdo City, China // Scientific Reports. - 2019. - V. 9. - Article 2471.

64. The role of humic substances in drinking water in Kashin-Beck disease in China / A. Peng, W.-H. Wang, C.-X. Wang, Z.-J. Wang, H.-F. Rui, W.-Z. Wang, Z.-W. Yang // Environmental Health Perspectives. - 1999. - V. 107. - P. 293-296.

65. Sudre P., Mathieu F. Kashin-Beck disease: from etiology to prevention or from prevention to etiology? // International Orthopaedics. - 2001. - V. 25. - P. 175-179.

66. Yao Y., Pei F., Kang P. Selenium, iodine, and the relation with Kashin-Beck Disease // Nutrition. - 2011. - V. 27. - P. 1095-1100.

67. Zinc: the other suspected environmental factor in Kashin-Beck disease in addition to selenium / X., Wang Y. Ning, L. Yang, F. Yu, X. Guo // Biological Trace Element Research. - 2017. V. 179. - P. 178-184.

Поступила 12.07.2020 2.

\section{Информация об авторах}

Рихванов Л.П., доктор геолого-минералогических наук, профессор отделения геологии Инженерной школы природных ресурсов Национального исследовательского Томского политехнического университета.

Соктоев Б.P., кандидат геолого-минералогических наук, доцент отделения геологии Инженерной школы природных ресурсов Национального исследовательского Томского политехнического университета.

Барановская Н.В., доктор биологических наук, профессор отделения геологии Инженерной школы природных ресурсов Национального исследовательского Томского политехнического университета.

Azеева E.B., инженер отделения геологии Инженерной школы природных ресурсов Национального исследовательского Томского политехнического университета.

Беляновская А.И., кандидат геолого-минералогических наук, инженер-исследователь отделения геологии Инженерной школы природных ресурсов Национального исследовательского Томского политехнического университета.

Дериглазова М.A., аспирант отделения геологии Инженерной школы природных ресурсов Национального исследовательского Томского политехнического университета. 
Юсупов Д.В., кандидат геолого-минералогических наук, доцент кафедры геологии и природопользования Амурского государственного университета; доцент отделения геологии Инженерной школы природных ресурсов Национального исследовательского Томского политехнического университета.

Эnова $\boldsymbol{E}$.C., кандидат геолого-минералогических наук, научный сотрудник лаборатории геохимии и рудогенеза Института природных ресурсов, экологии и криологии Сибирского отделения Российской академии наук.

Солодухина М.A., кандидат географических наук, научный сотрудник лаборатории геохимии и рудогенеза Института природных ресурсов, экологии и криологии Сибирского отделения Российской академии наук.

Замана Л.В., кандидат геолого-минералогических наук, ведущий научный сотрудник лаборатории геоэкологии и гидрогеохимии Института природных ресурсов, экологии и криологии Сибирского отделения Российской академии наук.

Михайлова Л.А., кандидат медицинских наук, заведующая кафедрой гигиены Читинской государственной медицинской академии.

Большунова T.C., кандидат геолого-минералогических наук, ведущий инженер отдела экологического нормирования управления экологии $\mathrm{AO}$ «ТомскНИПИнефть».

Миронова A.C., аспирант отделения геологии Инженерной школы природных ресурсов Национального исследовательского Томского политехнического университета.

Наркович Д.В., кандидат геолого-минералогических наук, доцент отделения геологии Инженерной школы природных ресурсов Национального исследовательского Томского политехнического университета.

Судыко А.Ф., инженер отделения геологии Инженерной школы природных ресурсов Национального исследовательского Томского политехнического университета.

Полякова Д.А., магистрант отделения геологии Инженерной школы природных ресурсов Национального исследовательского Томского политехнического университета. 
UDC 550.42:504(571.55)

\section{COMPREHENSIVE GEOCHEMICAL RESEARCH OF THE ENVIRONMENTAL COMPONENTS IN ENDEMIC AREAS OF TRANSBAIKALIA}

\author{
Leonid P. Rikhvanov1 \\ Bulat R. Soktoev 1 , \\ bulatsoktoev@tpu.ru \\ Natalia V. Baranovskaya ${ }^{1}$, \\ nata@tpu.ru \\ Elena V. Ageeva1, \\ ev_ageeva@mail.ru
}

\section{Alexandra I. Belyanovskaya ${ }^{1}$, aib28@tpu.ru}

Mariya A. Deriglazova1, belyakinama@gmail.com

Dmitry V. Yusupov ${ }^{1,2}$, yusupovd@mail.ru

Ekaterina S. Epova 3 , apikur1@ya.ru

1 National Research Tomsk Polytechnic University, 30, Lenin avenue, Tomsk, 634050, Russia.

2 Amur State University, 21, Ignatievskoe highway, Blagoveshchensk, 675027, Russia.

3 Institute of Natural Resources, Ecology, and Cryology, Siberian Branch of the Russian Academy of Sciences, 16a, Nedorezov street, Chita, 672002, Russia.

4 Chita State Medical Academy, 39a, Gorky street, Chita, 672000, Russia.

5 Tomsk Oil and Gas Research and Design Institute, 72, Mira avenue, Tomsk, 634027, Russia.

\author{
Mariya A. Solodukhina ${ }^{3}$ \\ mabn@ya.ru
}

Leonid V. Zamana ${ }^{3}$, I.v.zamana@mail.ru

Larisa A. Mikhailova4, mihailova-la@mail.ru

\section{Tatiana S. Bolshunova ${ }^{5}$,} bts26@mail.ru

Anastasiya S. Mironova', nasie2710@gmail.com

Dina V. Narkovich ${ }^{1}$, shvezova_d@mail.ru

Alexander F. Sudyko', sudykoaf@yandex.ru

Darya A. Polyakova1, darya.darya2012@mail.ru

The relevance of the research. Kashin-Beck disease, or Urov disease, is a classic example of endemic diseases. However, unlike other diseases, the cause of this one has not yet been determined. Currently, the scientists discuss more than 20 theories and hypotheses that explain its etiology and factors. The priority theory is the biogeochemical one, according to which the occurrence and history of the disease depends on the environmental factor (lack/excess of chemical elements or compounds). In this regard, the study of the environmental geochemistry in the area of Kashin-Beck disease is relevant.

The main aim of the research is to assess the environmental components geochemical features in the territory of south-eastern Transbaikalia, area of Kashin-Beck disease distribution.

Objects: environmental components - soil, bottom sediments, natural waters (surface, underground), drinking water salt sediments, core of tree rings, poplar leaves, lichen, moss, wormwood, potato, children's hair, bones of domestic pig.

Methods: instrumental neutron activation analysis and inductively coupled plasma mass spectrometry for detection of chemical composition of environmental components; processing of the obtained data included normalization of chemical elements content relative to background values (the noosphere clarke, water of Lake Baikal) and calculation of indicative ratios.

Results. The content of 26 (instrumental neutron activation analysis) and 62 (inductively coupled plasma mass spectrometry) chemical elements in 13 environmental components was studied. In the element composition of all the studied components, a regional geochemical association (Zn-Pb-Ba-Sb-As-Bi-Au) was identified, associated with the features of the regional metallogeny. For future research, the most informative components are natural waters, bone tissue, and children's hair. The most contrasting geochemical specialization of the environment is formed in settlements where, according to literature data, the maximum incidence of Kashin-Beck disease is observed. The disease etiology is multifactorial: natural conditions play an important role in the development of the disease, which leads to an imbalance in the element composition of the environmental components and, respectively, the human body.

Key words:

Kashin-Beck disease, Urov disease, south-eastern Transbaikalia, environmental geochemistry, indicative ratios. 
The research was carried out within the Program of enhancement of TPU competitiveness among the leading world's research centers. ICP-MS analysis was performed within the framework of the grant from the Russian Foundation for Basic Research (project no. 19-35-90061). Data processing and interpretation of the results were performed within the framework of the grant from the Russian Science Foundation (project no. 20-64-47021).

\section{REFERENCES}

1. Spravochnik po geokhimicheskim poiskam poleznykh iskopaemym [Handbook of geochemical prospecting for minerals]. Ed. by A.P. Solovyov. Moscow, Nedra Publ., 1990. 335 p.

2. Khimicheskiy analiz $v$ geologii $i$ geokhimii [Chemical analysis in geology and geochemistry]. Ed. by G.N. Anoshin. Novosibirsk, Geo Academic Publ., 2016. 622 p.

3. Rikhvanov L.P., Abrosimova N.A., Baranovskaya N.V., Bolshunova T.S., Gorbatyuk E.A., Edelev A.V., Mezhibor A.M., Myagkaya I.N., Soktoev B.R., Yusupov D.V., Belan L.N., Bortnikova S.B., Gustaytis M.A., Zhmodik S.M., Ischuk N.V., Kirichenko I.S., Narkovich D.V., Lazareva E.V., Olenchenko V.V., Saeva O.P., Saryg-ool B.Yu., Usmanova T.V., Yurkevich N.V. Biogeokhmicheskiy monitoring $v$ rayonakh khvostokhranilishch gornodobyvayushchikh predpriyatiy s uchetom mikrobiologicheskikh faktorov transformatsii mineralnykh komponentov [Biogeochemical monitoring of tailings of mining industry, taking into account microbiological factors of the mineral component transformation]. Novosibirsk, SB RAS Publ., 2017. 437 p.

4. Damperov N.I. Karta rasprostraneniya urovskoy bolezni [Map of Urov disease distribution]. Urovskaya bolezn v Zabaykalye [Urov disease in Transbaikalia]. Irkutsk, 1934. pp. 15-23.

5. Khachumova K.G., Lytkina K.A., Ilyina E.Yu. Kashin-Beck disease: diagnostics, differential diagnosis. Bulletin of Russian State Medical University, 2010, no. 6, pp. 15-19. In Rus.

6. Allander E. Kashin-Beck disease. An analysis of research and public health activities based on a bibliography 1849-1992. Scandinavian Journal of Rheumatology, 1994, vol. 23, pp. 1-36.

7. Yamamuro T. Kashin-Beck disease: a historical overview. International Orthopaedics, 2001, vol. 25, pp. 134-137.

8. Stone R. A medical mystery in middle China. Science, 2009, vol. 324, pp. 1378-1381.

9. Big bone disease: a multidisciplinary approach of Kashin-Beck disease in Tibet Autonomous Region (P.R. China). Eds. F. Malaisse, F. Mathieu. Gembloux, Les Presses Agronomiques de Gembloux, 2008. $148 \mathrm{p}$.

10. Ivanova M.A., Ivanov O.M. New medical technologies in the study of the Kashin-Beck disease and COPD. Journal of New Medical Technologies, 2017, vol. 24, no. 4, pp. 209-218. In Rus.

11. Wang K., Yu J., Liu H., Liu Y., Liu N., Cao Y., Zhang X., Sun D. Endemic Kashin-Beck disease: A food-sourced osteoarthropathy. Seminars in Arthritis and Rheumatism, 2020, vol. 50, pp. 366-372.

12. Gosudarstvennaya geologicheskaya karta Rossiyskoy Federatsii. Masshtab 1:1000000 (tretye pokolenie). List M-50 - Borzya. Obyasnitelnaya zapiska [State geological map of the Russian Federation. Scale 1:1000000 (third edition). Chart sheet M-50 - Borzya. Explanatory note]. St. Petersburg, Cartographic enterprise of A.P. Karpinsky Russian Geological Research Institute, 2010. $553 \mathrm{p}$.

13. Guo X., Ning Y., Wang X. Selenium and Kashin-Beck disease. Selenium: Chemistry, Analysis, Function and Effects (Food and Nutritional Components in Focus). Ed. by V.R. Preedy. Cambridge, Royal Society of Chemistry, 2015. pp. 552-571.

14. Du B., Zhou J., Zhou J. Selenium status of children in KashinBeck disease endemic areas in Shaanxi, China: assessment with mercury. Environmental Geochemistry and Health, 2018, vol. 40, pp. 903-913.

15. Liu H., Yu F., Shao W., Ding D., Yu Z., Chen F., Geng D., Tan X., Lammi M.J., Guo X. Associations between selenium content in hair and Kashin-Beck disease/Keshan disease in children in northwestern China: a prospective cohort study. Biological Trace Element Research, 2018, vol. 184, pp. 16-23.

16. Wang L., Yin J., Yang B., Qu C., Lei J., Han J., Guo X. Serious selenium deficiency in the serum of patients with Kashin-Beck disease and the effect of nano-selenium on their chondrocytes. Biological Trace Element Research, 2020, vol. 194, pp. 96-104.

17. Anikina L.V., Nikitina L.P. Selen. Ekologiya, patologiya, korrektsiya [Selenium. Ecology, patology, correction]. Chita,
Printing and publications center of Chita State Medical Academy, 2002. $400 \mathrm{p}$.

18. Glazovskaya M.A. Geokhimiya prirodnykh i tekhnogennykh landshaftov SSSR [Geochemistry of natural and technogenic landscapes of USSR]. Moscow, Vysshaya shkola, 1988. 328 p.

19. Vetrov V.A., Kuznetsova A.I., Sklyarova O.A. Baseline levels of chemical elements in the water of Lake Baikal. Geography and Natural Resources, 2013, vol. 34, pp. 228-238.

20. Yazikov E.G., Talovskaya A.V., Zhornyak L.V. Otsenka ekologogeokhimicheskogo sostoyaniya territorii g. Tomska po dannym izucheniya pyleaerozoley i pochv [Assessment of ecogeochemical conditions of Tomsk city according to investigations of dust aerosols and soils]. Tomsk, Tomsk Polytechnic University Publ., 2010. $264 \mathrm{p}$.

21. Pye K., Blott S.J. Comparison of soils and sediments using major and trace element data. Geological Society Special Publication, 2004, vol. 232, pp. 183-196.

22. He Z.L., Yang X.E., Stoffella P.J. Trace elements in agroecosystems and impacts on the environment. Journal of Trace Elements in Medicine and Biology, 2005, vol. 19, pp. 125-140.

23. De Albuquerque Pereira B., Da Silva Y.J.A.B., Do Nascimento C.W.A., Da Silva Y.J.A.B., Nascimento R.C., Boechat C.L., Barbosa R.S., Singh V.P. Watershed scale assessment of rare earth elements in soils derived from sedimentary rocks. Environmental Monitoring and Assessment, 2019, vol. 191, article 514

24. Alekseev A.O., Kalinin P.I., Alekseeva T.V. Soil indicators of paleoenvironmental conditions in the south of the East European Plain in the Quaternary time. Eurasian Soil Science, 2019, vol. 52, pp. 349-358.

25. Aleksentseva N.N. Ekologo-geokhimicheskie osobennosti territorii Yugo-Vostochnogo Zabaikalya, endemichnoy po bolezni KashinaBeka. Avtoreferat Dis. Kand. nauk [Ecogeochemical features of South-Eastern Transbaikalia territory endemic on Kashin-Beck disease. Cand. Diss. Abstract]. Minsk, 1987. 20 p.

26. Strakhovenko V.D. Geokhimiya donnykh otlozheniy malykh kontinentalnykh ozer Sibiri. Avtoreferat Dis. Dokt. nauk [Geochemistry of bottom sediments of small continental lakes of Siberia. Dr. Diss. Abstract]. Novosibirsk, 2011.33 p.

27. Ivanov A.Yu. Ekogeokhimiya donnykh otlozheniy malykh vodoemov yuga Tomskoy oblasti. Avtoreferat Dis. Kand. nauk [Environmental geochemistry of bottom sediments in small lakes of Tomsk Oblast southern part. Cand. Diss. Abstract]. Tomsk, 2018. $22 \mathrm{p}$.

28. Li M., Zhang Q., Sun X., Karki K., Zeng C., Pandey A., Rawat B., Zhang F. Heavy metals in surface sediments in the transHimalayan Koshi River catchment: distribution, source identification and pollution assessment. Chemosphere, 2020, vol. 244, article 125410 .

29. Zamana L.V., Rikhvanov L.P., Soktoev B.R., Baranovskaya N.V., Epova E.S., Solodukhina M.A., Mikhailova L.A., Kopylova Y.G., Khvashchevskaya A.A. New data on chemical composition of natural waters in the area of distribution of Urov (Kaschin-Beck) disease (Transbaikal region). Bulletin of the Tomsk Polytechnic University, Geo Assets Engineering, 2019, vol. 330, no. 1, pp. 121-133. In Rus.

30. Vinogradov A.P. Geokhimicheskie issledovaniya v oblasti rasprostraneniya urovskoy endemii [Geochemical investigations in the area of Urov endemia]. Doklady of AS USSR, 1939, vol. 23, no. 1, pp. 64-67. In Rus.

31. Voschenko A.V., Chugaev V.N., Vaistukh S.I., Butko V.S. K etiologii urovskoy (Kashina-Beka) bolezni [On the etiology of Urov (Kashin-Beck) disease]. Pediatriya: voprosy diagnostiki i lecheniya: tezisy dokladov nauchno-prakticheskoy konferentsii [Pediatry: questions of diagnosis and treatment: proceedings of research and practical conference]. Chita, Chita State Medical Academy Publ., 1988. pp. 20-23.

32. Butko V.S. Soderzhanie $i$ sootnoshenie nekotorykh makro- $i$ mikroelementov vo vneshney srede $v$ rayone urovskoy endemii Vostochnogo Zabaikalya. Avtoreferat Dis. Kand. nauk [Content 
and ratio of some macro- and trace elements in the environment and human tissues in the area of Urov endemia (Eastern Transbaikalia). Cand. Diss. Abstract]. Chita, 1973. 24 p.

33. Butko V.S. Soderzhanie nekotorykh mikroelementov v ratsionakh zhiteley urovskoy endemii [Some trace elements content in the dietary of Urov endemia residents]. Voprosy meditsinskoy ekologii $i$ problem uluchsheniya zdorovya naseleniya Zabaikalya I KNDR [Questions of medical ecology and problems of health improvement of Transbaikalia and DPRK population]. Chita, Chita State Medical Academy Publ., 1989. pp. 79-80.

34. Soktoev B.R., Rikhvanov L.P., Baranovskaya N.V., Zamana L.V., Rudmin M.A., Epova E.S., Solodukhina M.A., Etenko K.A., Mikhailova L.A., Kholmogorova I.V. Mineral and geochemical features of Yamkun spring (Transbaikal region). Bulletin of the Tomsk Polytechnic University. Geo Assets Engineering, 2019, vol. 330, no. 7, pp. 140-154. In Rus.

35. Rikhvanov L., Baranovskaya N., Soktoev B., Mongolina T. Evaluation of drinking water according to geochemical composition of its salt deposition. $8^{\text {th }}$ International Conference on Environmental Engineering. Vilnius, Vilnius Gediminas Technical University Publ. «Technika», 2011. pp. 337-342.

36. Soktoev B.R., Rikhvanov L.P., Matveenko I.A. Mineralogical and geochemical characteristics of drinking water salt deposits. IOP Conference Series: Earth and Environmental Science, 2015, vol. 27, Article 012042.

37. Yusupov D.V., Rikhvanov L.P., Baranovskaya N.V., Yalaltdinova A.R. Geochemical features of poplar leaf elemental composition in urban areas. Bulletin of the Tomsk Polytechnic University, Geo Assets Engineering, 2016, vol. 327, no. 6, pp. 25-36. In Rus.

38. Kosheleva N.E., Timofeev I.V., Kasimov N.S., Sandag E.-A. Geochemical transformation of soil cover and woody vegetation in the largest industrial and transport center of Northern Mongolia (Darkhan). Applied Geochemistry, 2019, vol. 107, pp. 80-90.

39. Yusupov D.V., Baranovskaya N.V., Robertus Y.V., Radomskaya V.I., Pavlova L.M., Sudyko A.F., Rikhvanov L.P. Rare earth elements in poplar leaves as indicators of geological environment and technogenesis. Environmental Science and Pollution Research, 2020, vol. 27, pp. 27111-27123.

40. Bargali R. Biogeokhimiya nazemnykh rasteniy [Biogeochemistry of terrestrial plants]. Moscow, GEOS Publ., 2005. 454 p.

41. Rikhvanov L.P., Arhangelskaya T.A., Zamyatina Yu.L. Dendroradiografiya kak metod retrospektivnoy otsenki radioekologicheskoy situatsii [Dendroradiography as a method of retrospective assessment of radioecological situation]. Tomsk, Tomsk Polytechnic University Publ., 2015. 148 p.

42. Turkyilmaz A., Sevik H., Isinkaralar K., Cetin M. Use of tree rings as a bioindicator to observe atmospheric heavy metal deposition. Environmental Science and Pollution Research, 2019, vol. 26, pp. 5122-5130.

43. Eby N. The smelters and the tree - an environmental story. Geology Today, 2020, vol. 36, no. 2, pp. 59-63.

44. Agnan Y., Séjalon-Delmas N., Claustres A., Probst A. Investigation of spatial and temporal metal atmospheric deposition in France through lichen and moss bioaccumulation over one century. Science of the Total Environment, 2015, vol. 529, pp. 285-296.

45. Malikova I.N., Strakhovenko V.D., Shcherbov B.L. Distribution of radionuclides in moss-lichen cover and needles on the same grounds of landscape-climatic zones of Siberia. Journal of Environmental Radioactivity, 2019, vol. 198, pp. 64-78.

46. Kudrevatykh I.Y., Kalinin P.I., Alekseev A.O. Biogenic accumulation of chemical elements by plants of Genus Poaceae Barnhart and Genus Artemisia L. in the dry steppe and semidesert zones of the south of the Russian Plain. Contemporary Problems of Ecology, 2019, vol. 12, pp. 377-385.

47. Han Z., Wan D., Tian H., He W., Wang Z., Liu Q. Pollution assessment of heavy metals in soils and plants around a molybdenum mine in central China. Polish Journal of Environmental Studies, 2019, vol. 28, pp. 123-133.

48. Hussain R., Luo K., Liang H., Hong X. Impact of the coal miningcontaminated soil on the food safety in Shaanxi, China. Environmental Geochemistry and Health, 2019, vol. 41, pp. 1521-1544.

49. Adamo P., Zampella M., Quétel C.R., Aversano R., Dal Piaz F., De Tommasi N., Frusciante L., Iorizzo M., Lepore L., Carputo D. Biological and geochemical markers of the geographical origin and genetic identity of potatoes. Journal of Geochemical Exploration, 2012, vol. 121, pp. 62-68.
50. Vitkovskiy Yu.A., Mikhailova L.A., Nondarevich E.A., Solodukhina M.A., Epova E.S., Eremin O.V., Alekseeva O.G., Burlaka N.M., Lapa S.E., Baranovskaya N.V., Ageeva E.V. Influence of anthropogenic geochemical environmental factors on the element status of children in Khapcheranga (Eastern Transbaikalia). Transbaikalian Medical Bulletin, 2018, no. 2, pp. 14-23. In Rus.

51. Wang X., Ning Y., Zhang P., Li C., Zhou R., Guo X. Hair multibioelement profile of Kashin-Beck disease in the endemic regions of China. Journal of Trace Elements in Medicine and Biology, 2019, vol. 54, pp. 79-97.

52. Guo Y., Li H., Yang L., Li Y., Wei B., Wang W., Gong H., Guo M., Nima C., Zhao S., Wang J. Trace element levels in scalp hair of school children in Shigatse, Tibet, an endemic area for Kaschin-Beck disease (KBD). Biological Trace Element Research, 2017, vol. 180, pp. 15-22.

53. Baranovskaya N.V., Rikhvanov L.P. Elementny sostav organov i tkaney domashnikh zhivotnykh (Sus scrofa domesticus (Artio dactila, Mammalia)) kak indikator sredy obitaniya [Elemental composition of organs and tissues of domestic animals (Sus scrofa domesticus (Artio dactila, Mammalia)) as an indicator of habitat]. Problemy biogeokhimii i geokhimicheskoy ekologii, 2011, no. 3, pp. 74-84.

54. Rikhvanov L.P., Baranovskaya N.V., Korogod N.P., Khvashchevskaya A.A., Kopylova Y.G., Mazurova I.S., Mukanova R.Z., Turkbenov T.K., Skripnik M.I., Belyanovskaya A.I. Elemental composition of biological water as an indicator of technogenesis. Bulletin of the Tomsk Polytechnic University, Geo Assets Engineering, 2016, vol. 330, no. 2, pp. 214-223. In Rus.

55. Belyanovskaya A., Laratte B., Perry N., Baranovskaya N. A regional approach for the calculation of characteristic toxicity factors using the USEtox model. Science of the Total Environment, 2019, vol. 655 , pp. 676-683.

56. Chepurov K.P., Cherkasova A.V., Akulov N.M., Ostrovskiy I.I., Martynyuk D.F. Urovskaya bolezn [Urov disease]. Blagoveschensk, Amur book Publ. house, 1955. $199 \mathrm{p}$.

57. Reynberg S.A. Rentgenodiagnostika zabolevaniy kostey $i$ sustavov [X-ray diagnosis ща musculoskeletal disorders]. $4^{\text {th }}$ ed. Moscow, Meditsina Publ., 1964. Vol. 1, 529 p.

58. Deriglazova M.A., Rikhvanov L.P., Baranovskaya N.V., Ilenok S.S. Reflection of the habitat in the mineralogical features of the ash residues of a human organism. Transbaikal State University Journal, 2019, vol. 25, no. 10, pp. 6-14. In Rus.

59. Skinner C.W. Mineralogy of bone. Essentials of medical geology. Dordrecht, Springer, 2013. pp. 665-687.

60. Vinogradov A.P. O prichinakh proiskhozhdeniya urovskoy endemii (geokhimicheskie issledovaniya) [On reasons of Urov disease genesis (geochemical investigations)]. Trudy Biogeokhimicheskoy laboratorii [Publications of Biogeochemical Laboratory]. Moscow, AS USSR Publ., 1949, vol. 9. pp. 5-29.

61. Ermakov V.V., Gulyaeva U.A., Tyutikov S.F., Kuzmina T.G., Safonov V.A. Biogeochemistry of calcium and strontium in the landscapes of Eastern Transbaikalia. Geochemistry International, 2017, vol. 55, pp. 1105-1117.

62. Ermakov V., Bech J., Gulyaeva U., Tyutikov S., Safonov V., Danilova V., Roca N. Relationship of the mobile forms of calcium and strontium in soils with their accumulation in meadow plants in the area of Kashin-Beck endemia. Environmental Geochemistry and Health, 2020, vol. 42, pp. 159-171.

63. Zha X., Gao X. Ecological analysis of Kashin-Beck osteoarthropathy risk factors in Tibet's Qamdo City, China. Scientific Reports, 2019, vol. 9, Article 2471.

64. Peng A., Wang W.-H., Wang C.-X., Wang Z.-J., Rui H.-F., Wang W.-Z., Yang Z.-W. The role of humic substances in drinking water in Kashin-Beck disease in China. Environmental Health Perspectives, 1999, vol. 107, pp. 293-296.

65. Sudre P., Mathieu F. Kashin-Beck disease: from etiology to prevention or from prevention to etiology? International Orthopaedics, 2001, vol. 25, pp. 175-179.

66. Yao Y., Pei F., Kang P. Selenium, iodine, and the relation with Kashin-Beck Disease. Nutrition, 2011, vol. 27, pp. 1095-1100.

67. Wang X., Ning Y., Yang L., Yu F., Guo X. Zinc: the other suspected environmental factor in Kashin-Beck disease in addition to selenium. Biological Trace Element Research, 2017, vol. 179, pp. 178-184.

Received: 20 July 2020. 


\section{Information about the authors}

Leonid P. Rikhvanov, Dr. Sc., professor, National Research Tomsk Polytechnic University.

Bulat R. Soktoev, Cand. Sc., assistant professor, National Research Tomsk Polytechnic University.

Natalia V. Baranovskaya, Dr. Sc., professor, National Research Tomsk Polytechnic University.

Elena V. Ageeva, engineer, National Research Tomsk Polytechnic University.

Alexandra I. Belyanovskaya, Cand. Sc., research engineer, National Research Tomsk Polytechnic University.

Mariya A. Deriglazova, postgraduate student, National Research Tomsk Polytechnic University.

Dmitry V. Yusupov, Cand. Sc., assotiate professor, Amur State University; assotiate professor, National Research Tomsk Polytechnic University.

Ekaterina S. Epova, Cand. Sc., research scientist, Institute of Natural Resources, Ecology, and Cryology.

Mariya A. Solodukhina, Cand. Sc., research scientist, Institute of Natural Resources, Ecology, and Cryology.

Leonid V. Zamana, Cand. Sc., leading research scientist, Institute of Natural Resources, Ecology, and Cryology.

Larisa A. Mikhailova, Cand. Sc., head of the department, Chita State Medical Academy.

Tatiana S. Bolshunova, Cand. Sc., engineer, Tomsk Oil and Gas Research and Design Institute.

Anastasiya S. Mironova, postgraduate student, National Research Tomsk Polytechnic University.

Dina V. Narkovich, Cand. Sc., assotiate professor, National Research Tomsk Polytechnic University.

Alexander F. Sudyko, engineer, National Research Tomsk Polytechnic University.

Darya A. Polyakova, master student, National Research Tomsk Polytechnic University. 